Florida International University FIU Digital Commons

\title{
A Study on Residents' Perceptions and Attitudes Towards the Vieques National Wildlife Refuge in Puerto Rico
}

\author{
Ana C. Guzman \\ Florida International University, aguzm060@fiu.edu
}

DOI: $10.25148 /$ etd.FIDC000290

Follow this and additional works at: https://digitalcommons.fiu.edu/etd

Part of the Environmental Sciences Commons

\section{Recommended Citation}

Guzman, Ana C., "A Study on Residents' Perceptions and Attitudes Towards the Vieques National Wildlife Refuge in Puerto Rico" (2016). FIU Electronic Theses and Dissertations. 2434.

https://digitalcommons.fiu.edu/etd/2434 


\title{
FLORIDA INTERNATIONAL UNIVERSITY
}

Miami, Florida

\section{A STUDY ON RESIDENTS’ PERCEPTIONS AND ATTITUDES TOWARDS THE VIEQUES}

NATIONAL WILDLIFE REFUGE IN PUERTO RICO

\author{
A thesis submitted in partial fulfillment of \\ the requirements for the degree of \\ MASTER OF SCIENCE \\ in \\ ENVIRONMENTAL STUDIES \\ by \\ Ana Guzman
}


To: $\quad$ Dean Michael R. Heithaus

College of Arts, Sciences \& Education

This thesis, written by Ana Guzman, and entitled A Study on Residents' Perceptions and Attitudes Towards the Vieques National Wildlife Refuge in Puerto Rico, having been approved in respect to style and intellectual content, is referred to you for judgment.

We have read this thesis and recommend that it be approved.

David B. Bray

$\overline{\text { Ligia Collado-Vides }}$

Joel T. Heinen, Major Professor

Date of Defense: March 31, 2016

The thesis of Ana Guzman is approved.

Dean Michael R. Heithaus

College of Arts, Sciences \& Education

Andrés G. Gil

Vice President for Research and Economic Development and Dean of the University Graduate School

Florida International University, 2016 


\section{ACKNOWLEDGMENTS}

I am deeply indebted to my major advisor Dr. Joel Heinen, for his constant guidance, patience, motivation, and financial support throughout my graduate career, without which I could not have accomplished this work. I am extremely grateful to Dr. Ligia Collado-Vides and David Bray, whose mentorships have helped me through my research and will continue to be useful throughout my career. I also wish to acknowledge the help of Dr. Jay Sah for devoting not only his time and knowledge, but also providing me with his valuable critique and suggestions in developing the statistical analysis for this thesis.

I am tremendously thankful to the Fish and Wildlife Service in Vieques for their support throughout this entire project, especially Mike Barandiaran and Mitzuka Bermudez. In addition, I thank the Vieques Historical \& Conservation Trust, Radio Vieques, and all the other organizations and residents of Vieques that gave me their time and help in so many ways during this research. Furthermore, I am grateful to Mr. Ruperto Chaparro and the Sea Grant College Program at my alma mater, the University of Puerto Rico Mayagüez, for providing useful resources and insight for this research project. I convey special thanks to my friends, family and extended family both here and in Puerto Rico for their continued encouragement, emotional support, and assistance throughout my time at Florida International University. I would also like to extend my gratitude to the Department of Earth and Environment for providing me with a Teaching Assistantship, and the Graduate Minority Opportunities Program for supplementary financial support. 


\section{ABSTRACT OF THE THESIS \\ A STUDY ON RESIDENTS' PERCEPTIONS AND ATTITUDES TOWARDS THE VIEQUES NATIONAL WILDLIFE REFUGE IN PUERTO RICO \\ by}

Ana Guzman

Florida International University, 2016

Miami, Florida

Professor Joel T. Heinen, Major Professor

Conflicts between local people and protected areas can undermine conservation goals. This study explores perceptions towards Vieques National Wildlife Refuge (VNWR), a complex former military site containing a combination of high ecological value along with an array of unexploded ordnances. The purpose of this research is to evaluate how residents perceive VNWR and elucidate conflicts associated with former and current uses of the wildlife refuge. Here, I interviewed 235 residents of Vieques Island, Puerto Rico using semi-structured surveys and 33 key informants representing various stakeholder groups to assess attitudes toward VNWR.

A combination of factors influencing attitudes about VNWR included socio-economic status and misconceptions about management. Overall, residents did not express strong attitudes. However, older individuals and those living longer on Vieques generally had poorer attitudes than others. Among the most common reasons for expressing discontent were the restrictive regulations regarding access to VNWR and the limitations on resource extraction. 


\section{TABLE OF CONTENTS}

CHAPTER

PAGE

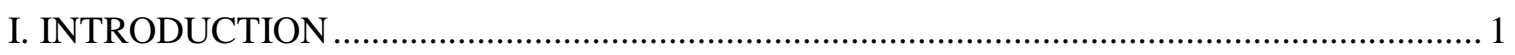

1. Protected areas (PA) and social research agendas in PA management ................................ 1

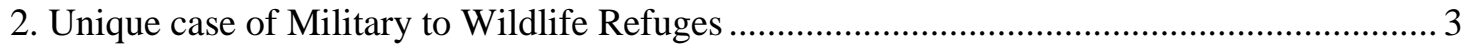

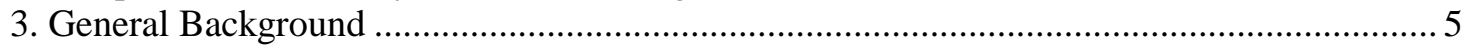

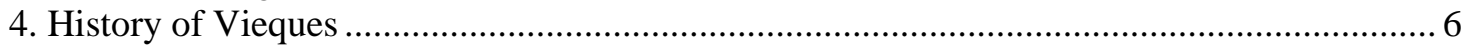

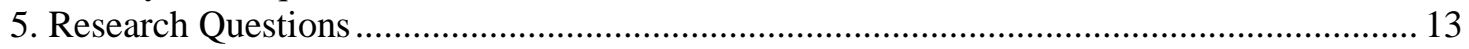

II. QUANTITATIVE ANALYSIS BY HOUSEHOLD SURVEYS: Evaluating the Attitudes and Level of Knowledge of Residents Towards the Vieques National Wildlife Refuge ................ 14

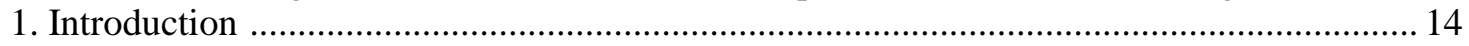

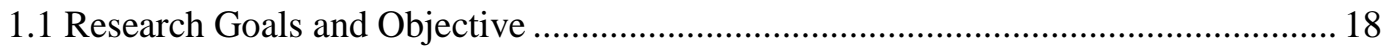

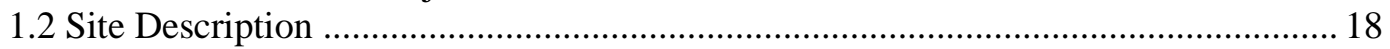

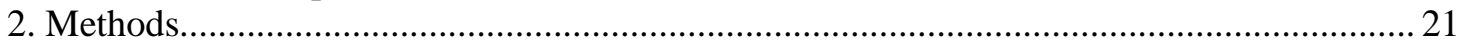

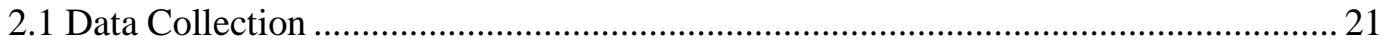

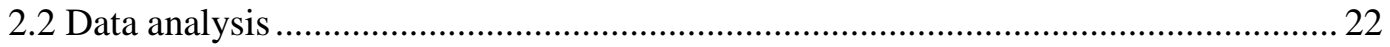

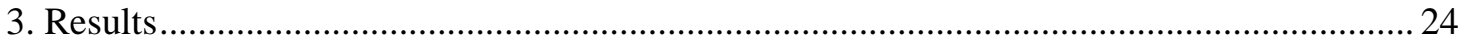

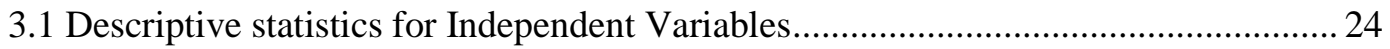

3.2 Attitude towards Vieques National Wildlife Refuge .............................................. 26

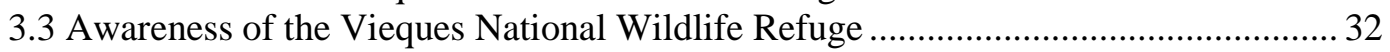

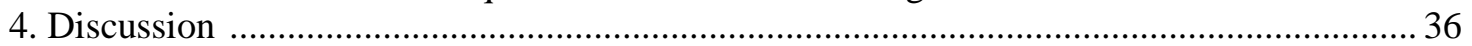

4.1 Attitude towards Vieques National Wildlife Refuge ................................................. 36

4.2 Awareness of the Vieques National Wildlife Refuge .................................................. 42

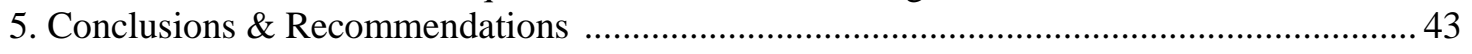

III. QUALITATIVE ANALYSIS OF KEY INFORMANT INTERVIEWS: Evaluating the Perceptions and Attitudes Towards the Vieques National Wildlife Refuge ............................ 45

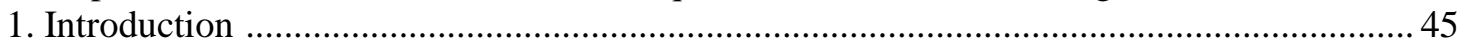

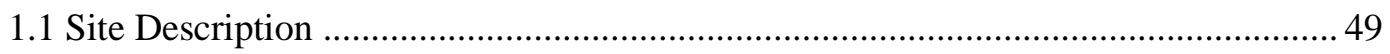

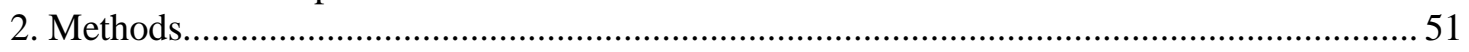

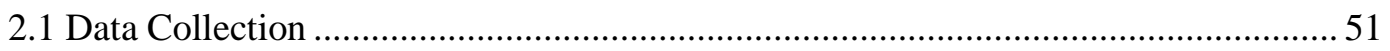

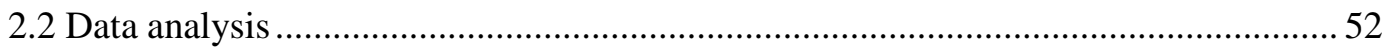

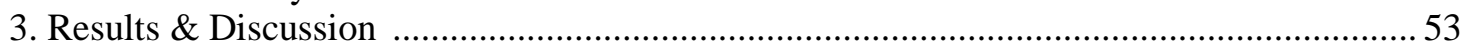

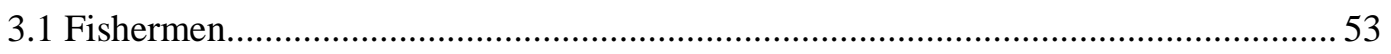

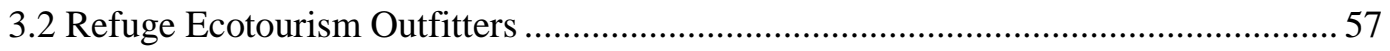

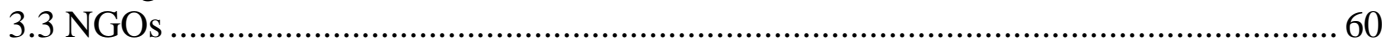

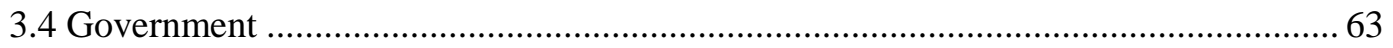

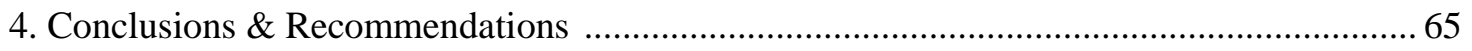

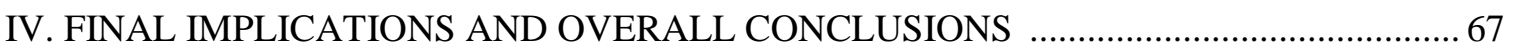

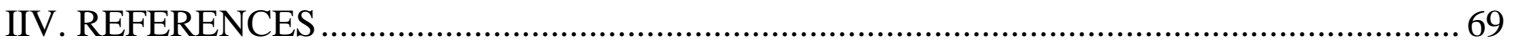

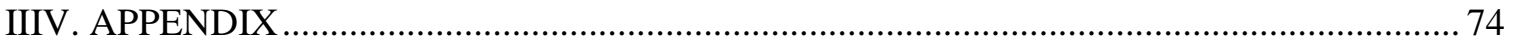




\section{LIST OF FIGURES}

FIGURES

PAGE

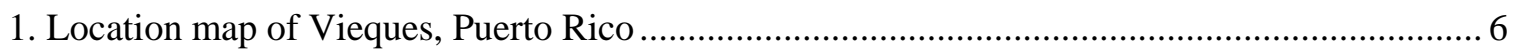

2. Map depicting region VNWR encompasses and areas closed off to the public ........................ 12

3. Mean attitude score of respondents based on birthplace ....................................................... 29

4. Mean attitude score of respondents per age in 3 intervals of approximately 20-years and

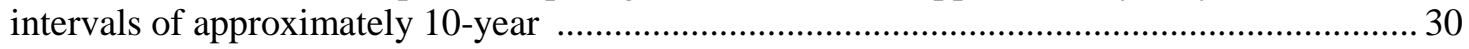

5. Mean attitude score for time living in Vieques divided into 10-year interval categories .......... 31

6. Mean attitude score of respondents based on birthplace......................................................... 33

7. Mean awareness score of respondents within each of the education levels .............................. 34

8. Mean awareness score for age of respondent divided into 10 -year intervals............................ 35

9. Mean awareness score for time survey respondents have lived in Vieques divided in 15-year

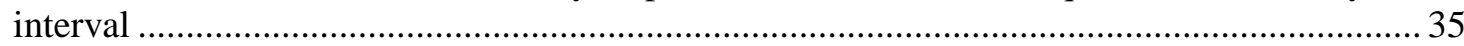




\section{INTRODUCTION}

\section{Protected areas (PA) and social research agendas in PA management}

The concept of protecting natural or semi-natural areas has been around for thousands of years, with examples such as royal hunting reserves as early as 700 B.C. (Runte, 1997) or ancient sacred groves in India dating back to 1500-500 B.C. (Ramakrishnan, 1996 in Briggs, 2009). The way these protected areas are defined has modified and evolved over time. At present, the widely accepted definition for a protected area is "a clearly defined geographical space, recognized, dedicated and managed, through legal or other effective means, to achieve the long-term conservation of nature with associated ecosystem services and cultural values”, as defined by IUCN in 2008 (Dudley, 2008). Currently, there are many different designations for protected areas such as national park, wildlife reserve, protected seascapes, marine sanctuary, wilderness area, community conserved areas, and national wildlife refuge. Each designation carries a unique level of regulations covering permissible activities. In the past, with strict forms of conservation many rural people dependent on local natural resources were marginalized. The inaccessibility to natural resources often undermined conservation goals as a result of growing tensions because of park-people conflicts, and ultimately drove to a global change in protected areas management along with associated research (Heinen, 2010). In the realm of social science research focused on conservation, many studies (e.g., Torn et al. 2008; Szell \& Hallett, 2013) suggest that it is essential to address local people’s perceptions and attitudes in the management of conservation areas. Nonetheless, in some regions strict conservation still occurs without taking into consideration the local people.

In the United States, one type of protected area set aside with the prime purpose of biological conservation is designated as a National Wild Refuge (NWR). These areas that are of interest to this study, form part of the US National Wildlife Refuge System managed by the US 
Fish and Wildlife Service (USFWS). According to the National Wildlife Refuge System Improvement Act of 1997, “The mission of the System is to administer a national network of lands and waters for the conservation, management, and where appropriate, restoration of the fish, wildlife, and plant resources and their habitats within the United States for the benefit of present and future generations of Americans”. With over 560 land units, the NWR system encompasses the largest network of federally owned lands dedicated mainly to biological conservation (Fischman, 2003). The Refuge system follows a dominant use policy where the primary goal is related to conservation, management, and restoration of wildlife and related resources. Secondary uses that commonly occur such as recreational, cultural, traditional, and/or economic activities can exist meanwhile not compromising primary goals. Therefore, it is important to understand social dimensions of NWRs as it can affect management and conservation goals.

A crucial component to creating a sustainable protected areas management plan is to comprehend stakeholders' perceptions and attitudes towards the plan (Allendorf, 2007). Socioeconomic factors that influence these perceptions may also be important to creating and implementing effective conservation policies, especially where perceptions are heavily influenced by current and past social and economic situations. Negative perceptions can potentially create conflicts in protected area management as local residents may hinder conservation goals. More positive perceptions of a refuge may be beneficial in attaining conservation goals as citizens actively participate in conservation. By comprehending how the local communities view protected areas, it is possible to create management plans that will mitigate the negative perceptions and take advantage of positive perceptions (Allendorf et al., 2006). An example of a successful socioeconomic approach in PA management is in the Florida Keys National Marine Sanctuary, where the integration of public perception and participation facilitated the development of a 151 nautical square mile no-take ecological reserve to protect the critical coral 
reef ecosystem of the Dry Tortugas (Shivlani, 2007; Haskell et al., 2000). Although the local communities' attitudes and involvement seem to be an important factor in PAs management, this is not commonly considered in developing countries where PAs are still set aside without informing or allowing participatory processes with local communities (Heinen, 2010). Similarly some NWR are designated under Congressional law without the involvement or consultation of local communities, municipal government, or state government. Often, the socio-economic conflicts that could emerge from these actions are not considered. In addition, protected areas including NWRs and their associated government agencies have been historically underfunded and understaffed. Thus, community involvement is essential as a way to mitigate these limitations that can ultimately effect enforcement of rules and regulations without community support (Tissot et al., 2009).

\section{Unique case of Military to Wildlife Refuges}

In over the past two decades there is an emerging form of land reclassification where military lands are converted to National Wildlife Refuges (NWR). This type of land reclassification has been referred to in various publications (e.g., Havlick, 2007, 2011, 2014; Hourdequin \& Havlick, 2011) as military-to-wildlife (M2W) conversion and M2W refuges. The M2W sites include military bases, weapons depots, munitions manufacturing facilitates, bombing ranges and military maneuvers grounds. There are currently twenty-one M2W refuges in the US and its territories, accounting for over one million acres of land (Havlick, 2007). Some examples of these locations include Vieques NWR (the focus of this study), Rocky Mountain Arsenal NWR, Big Oak NWR, and Great Bay NWR. These sites are unique and important because of the paradox they present and its implications to management and conservation practices. Because of the complexity of former military activities, M2W sites can contain both the highest biodiversity and highest contamination among federal lands. Thus, they present a great potential for 
environmental and biological conservation, although simultaneously posing numerous challenges. The incongruity is a result of the characteristic pattern presented by these sites: a heavily impacted core, surrounded by areas that were essentially sheltered from anthropogenic disturbances because they served as buffer zones, and access was significantly restricted (Havlick, 2011). Hence, in these surrounding areas traditional ecological impacts such as mining, logging, residential development and recreational or commercial activities did not occur (Havlick, 2011). These M2W sites, consequently, challenge traditional views on land categorization; terms such as pristine, degraded, natural, or artificial cannot fully describe these hybrid geographies (Whatmore, 2002; Havlick, 2011).

The M2W refuges face unique challenges as opposed to the traditional NWRs. These lands come with the inevitable inheritance of military relics that include unexploded ordnance, physically impacted landscapes, chemical contamination, explosive contaminants, depleted uranium, hazardous waste and reinforced structures such as bunkers or control posts (Havlick, 2007, 2011, 2015). The types of military installations that formerly existed on a refuge will define the challenges that refuge will face. For instance, a former bombing range will have a landscape affected by unexploded ordnances, physical craters and contamination. Meanwhile a former chemical manufacturing facility will have the challenges of toxic chemical contamination, to varying degrees and characterized by different toxins. Moreover, what is generally true for all M2W refuges is that they face unique health and safety hazards to both the public and the environment when compared to traditional NWRs. Likewise, refuge employees and managers are frequently not trained to deal with these situations. Other problems that are common in federal government environmental agencies are exacerbated such as the chronic shortage of funds. Cost of clean up and restoration for these highly contaminated lands is extremely high for already deficient budgets. Finally, the control over land management decisions is in cases limited because of the absence of land title or legal limitations during the clean up process even when refuge has 
been designated. All of these create unique challenges and conflicts in the management of M2W Refuges.

\section{General Background}

Vieques is an island municipality that forms part of the Commonwealth of Puerto Rico, an unincorporated territory of the United States of America. The island is located just seven miles off the southeast coast of Puerto Rico's mainland (Figure 1). The entire archipelago is situated on top of the northeastern edge of the Caribbean Plate, between the Atlantic Ocean on the north and the Caribbean basin to the south (Weil, 2004). Vieques has a land area of about $127.4 \mathrm{~km} 2$, with a length of approximately $33 \mathrm{~km}$ and width of $7 \mathrm{~km}$ (Bauer et al. 2008). According to the 2010 Census Bureau, the island had 9,301 residents. There are two main towns where most of the islands inhabitants live: Isabel II and Esperanza. The former is where city hall, central plaza, and the ferry dock are located, while the latter was a fishing village that has become a tourist destination in recent years with the integration of small guesthouses and restaurants. There are also some other barrios and sectors within the municipality with additional residential areas. Overall, Vieques is a rural island municipality. 
Figure 1 Location map of Vieques, Puerto Rico (Source: USFWS, 2007)

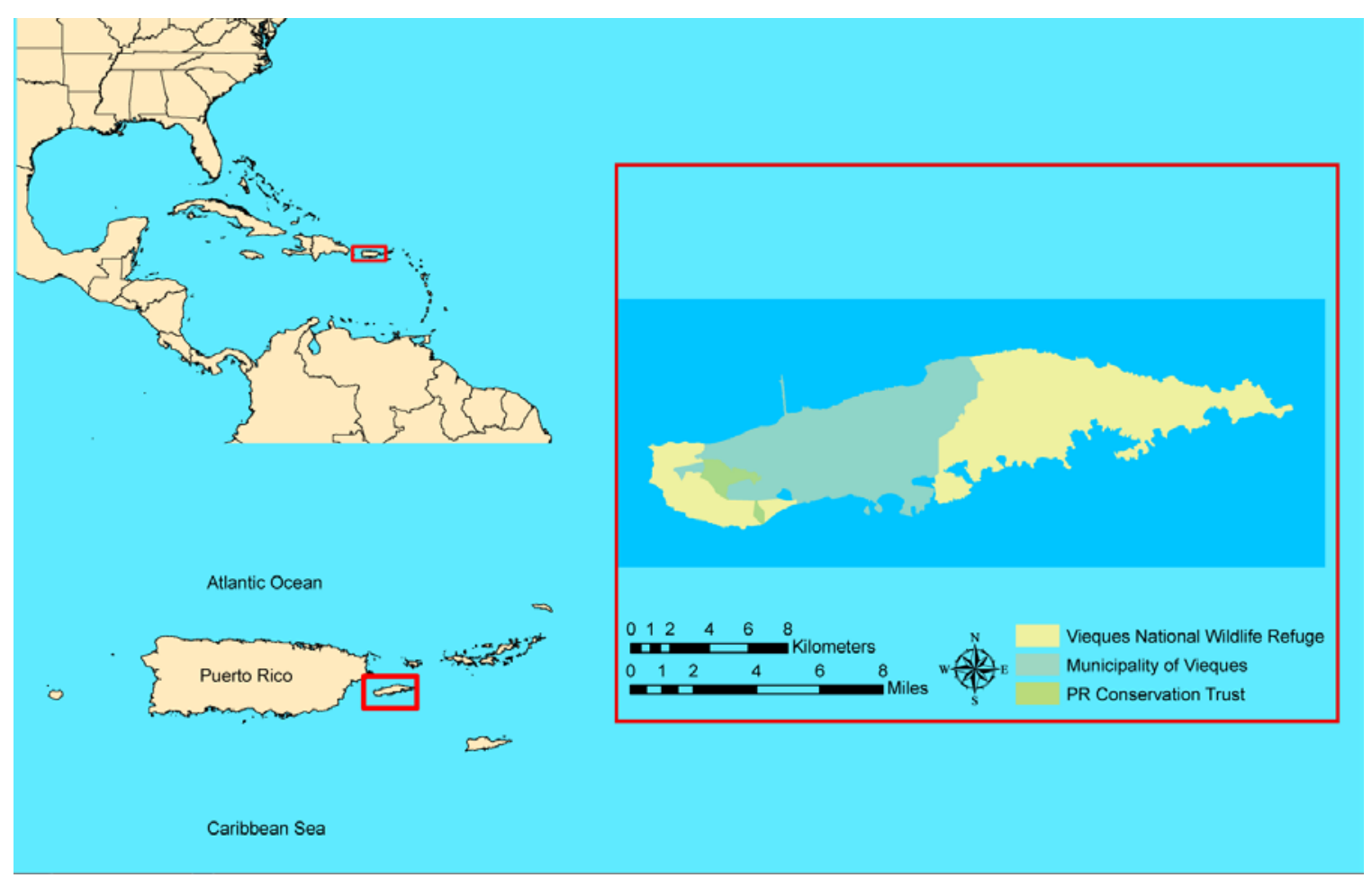

\section{History of Vieques}

The island of Vieques has experienced extensive environmental alteration and a variety of socioeconomic conditions throughout its history. The island was reportedly characterized by dense climax forest when inhabited by Native Americans (Langhorne, 1987; Bauer et al., 2008). However, landcover changed greatly after European settlement. England and Spain, and to a lesser degree Denmark, clashed over Vieques mostly because of the island's resources including its own water source, fertile soils considered suitable for sugar cultivation, and timber richness (McCaffrey, 2002). From the mid-seventeenth to the mid-nineteenth century European settlements existed on the island (McCaffrey, 2002). The first substantial environmental impact on the island was the overexploitation of forest resources through timber harvesting by the Europeans (Gemmill, 2015). Next, land clearing for sugar plantations that expanded during the 
nineteenth century caused significant land alteration, with peak sugarcane cultivation in 1920 (Langhorne, 1987). Soon after, during 1934 to 1935, sugarcane production reduced as a result of the Great Depression and sugar quotas. Subsequently, a shift from crop plantation to livestock production occurred in the mid 1900s (Bauer et al., 2008), which exacerbated natural habitat degradation through cattle grazing. As a result of the combined anthropogenic effects, an estimated $80 \%$ of the native flora had been altered by 1972, leading to a diverse landscape with various levels of succession, ranging from pastureland to secondary growth of scrub and woodland (Woodbury, 1972; Bauer et al., 2008). There is also a variety of marine habitats that have been directly and indirectly subjected to anthropogenic effects within the surrounding waters of Vieques, however, there is less data available in regards to environmental changes of these marine habitats. According to Bauer et al. (2008), there is evidence of an extensive reduction of coral cover on reefs adjacent to Vieques that is parallel to other locations in the Caribbean. A study by Hernandez-Cruz et al. (2006), where photographs dating from 1937-2000 were examined, identified a decline in A. palmate reefs in the Bahia Salina del Sur area, starting in the 1970s.

Moreover, apart from the environmental impact, Vieques suffered socioeconomic changes. Both Vieques and mainland Puerto Rico were considered a strategic military location during the Spanish colonial period. Their fundamental function was to secure Spain’s access to its colonies and guard the entrance to the Caribbean from invasions by its European enemies (McCaffrey, 2002). However, although Vieques was also considered important for military purposes, it remained secondary in importance to the mainland of Puerto Rico. After years of debate, in 1843, Spain finally committed the military resources necessary to establish its control over Vieques (McCaffrey, 2002). It is at this point that Vieques became formally part of the Spanish empire and officially part of Puerto Rico. In spite of the abundance of sugar cultivation, the economy of Vieques did not flourish as a consequence of limitations such of trade imposed by 
Spanish policies. For example, trade with non-Spanish Caribbean islands and the US was banned, significantly hindering economic development.

In 1898, after the Spanish-American war, Vieques passed to the control of the US government along with Puerto Rico as spoils. Economic hardships and social inequities continued to persist with the change in imperial power. Since economic conditions in Vieques were especially harsh (both before and after US annexation), many residents lived almost exclusively off the natural resources afforded by the land and sea (Shivlani, 2007). In addition, the majority of the lands were sugar cane plantations under the control of very few individuals. These plantation owners allowed their workers, also called agregados, to live on parcels within their land and grow subsistence crops and tend livestock, as well as to build modest homes. By the 1930s, ninety five percent of Vieques’ population had no land ownership and more than seventy percent of the lands were controlled by two sugar corporations (Shivlani, 2007). In the 1940’s, during World War II, the socioeconomic conditions of the majority of the residents of Vieques further declined. The US government expropriated nearly three-quarters of Vieques, displacing local residents from their homes, in order to establish a naval base and training facility (Baver, 2012).

Using the principle of eminent domain and greatly facilitated by US sugar quotas weakening Puerto Rican plantations, the Navy confiscated several properties in 1941, amounting to 21,100 acres at a cost of $\$ 1.04$ million (Shivlani, 2007). Subsequent expropriations added 4,340 acres (Shivlani, 2007). According to McCaffrey (2002), residents were allocated plots without land tittle and warned that eviction could occur if the Navy decided to reclaim the land. Many inhabitants lost their homes, their crops, and access to aquifers as the Navy was then under control of approximately two thirds of the island. Overall, the Navy had total control of transportation and development in civilian areas with their dominance over nautical routes, flight paths, and zoning laws (McCaffrey, 2006b; McCaffrey, 2008). Land expropriations occurred in 
the West and East sides of the island, leaving the civil population wedged between the newly acquired naval lands. In addition, the civilian area was only approximately eight miles from the live impact area of the bombing range, putting residents at potential risks. Further, residents had to travel twice the distance and through rough waters between Vieques and Puerto Rico in order to comply with nautical routes. Restricted zones in the coastal waters also imposed difficulties on many families who depended on fishing as a form of subsistence (McCaffrey, 2006).

The naval site that was established in Vieques hosted an ammunition depot on the western side of the island. The eastern portion of the island, accounting for the largest part of the naval occupancy, hosted a variety of firing practices, amphibious landings and training maneuvers. The maneuvers included air, ground, and water attacks that left a legacy of military relicts and environmental impacts. The island and surrounding waters were littered with munitions and unexploded ordnances (UXO). Many habitats were destroyed or degraded including the emerging secondary forest, mangroves, and coral reefs. The habitat destruction that occurred is particularly unfortunate as mangroves and coral reefs are ecosystems unique to tropical and subtropical regions facing a global decline. Bombardment on the land and water resulted in a physical impacted landscape littered with craters. A mosaic of patches with permanent coral reef loss is found within the physically impacted seascape (Hernández-Delgado, Montañez-Acuña, Otaño-Cruz \& Suleimán-Ramos, 2014).

Human and environmental contamination occurred due to the use of explosives, heavy metals, industrial solvents, and pesticides among other substances. In addition to the poverty, social inequity, economic hardships, and oppression experienced for decades by the islands inhabitants, Baver (2006) and McCaffrey (2011) have considered Vieques a case of social and environmental injustice. Vieques appeared to be mainly a strategic military locality and overall its socioeconomic necessities were disregarded. Moreover, Vieques never developed as the main island did, in terms of population and infrastructure (Shivlani, 2007). 
The Navy trained on Vieques an average of 180 days annually during the 1980s and the 1990s, dropping or firing an average of 1,328,118 kilograms of bombs and explosives per year (McCaffrey, 2008). In 1998 alone, the Navy dropped approximately 23,000 bombs on the island, the majority (approximately 16,000) of which contained live explosives (Marques \& FernandezPortes, 2001). In addition, it became apparent that there was a concern, not only for safety in case of a mishap, but that these Navy practices could be exposing the civilian population to hazardous contaminants. Some studies, such as Nazario et al. (1998), suggested correlations between bombings exercises on Vieques and the increase of cancer rates on the island. Earlier studies showed abnormal concentrations of nitramine explosives (RDX and HMX) in Vieques’ drinking water and air (Cruz Perez, 1988; Hoffsomer \& Glover, 1978; in Marques \& Fernandez-Portes, 2001).

Many Viequenses and fellow mainland citizens opposed military occupation and struggled for the termination of military activities along with the reclaiming of their land for many years. According to McCaffrey (2008), protests erupted in response to the intensification of maneuvers and live-fire exercises on the island in the late 1970s. Between 1978 and 1983, fisherman led a dramatic grassroots struggle against the military presences in Vieques (McCaffrey, 2008). Their main motivation was the impacts of military activities on their fishing livelihoods. When the Navy was undergoing training maneuvers, large portions of Vieques surrounding waters where closed off to residents. Furthermore, fishermen that used traps were susceptible to loss because often they were not even given the opportunity to retrieve their gear. In addition, this movement was also fueled by the desire of residents to recover their former lands. However, apart from gaining some benefits from the navy, the overall protests were unsuccessful.

While the protest temporarily ceased, the mid-1990s saw an increase in vocal social discontent; the proclamation of desires to regain formerly owned lands added to the fishermen' 
cause creating bigger unrest. Protest revolved largely around safety, environmental protection, and health. A pivotal point in the conflict occurred in 1999, when two F-18 fighter jets accidentally bombed a civilian manned naval observational post in eastern Vieques tragically killing one and wounding an additional four (Shivlani, 2007). The unfortunate event united a vast range of people from diverse groups: state government, municipal government, NGO's, churches of all denominations, schools, universities, and environmental groups unified towards the common goal. The demands became the demilitarization, decontamination, devolution and sustainable development of the lands that were rightfully owned by the Viequense. Mass mobilizations, constant pickets, thousands of civil disobedience acts, international involvement and attention from the media occurred during the subsequent four years from the incident (McCaffrey, 2008). In 2003, the US Navy retreated from Vieques; however, only 4,250 acres of the previously occupied land was transferred to the Municipality of Vieques and another 800 acres to the Puerto Rico Conservation Trust (Baver, 2012). The remaining 17,723 acres were transferred to the Fish and Wildlife Service (FWS) for the creation and management of the VNWR (Baver, 2012) (Figure 2). However, the creation of a federal protected area through a top bottom approach lead to an incomplete fulfillment of Viequenses' aspirations during their struggle, which included the recovery of the people’s previously owned land.

Unfortunately, there is still a legacy of contamination inherited by US Navy occupation. Hazardous substances were released into the environment and the unexploded ordnances left behind pose further health and safety issues (McCaffrey, 2006). As a result, several areas in Vieques where designated as Superfund sites and listed as national priority for clean up (McCaffrey, 2006; Baver, 2006). Superfund sites refer to uncontrolled or abandoned hazardouswaste sites listed under the Comprehensive Environmental Response, Compensation, and Liability Act (CERCLA) also know as Superfund (EPA, 2016). As required by US Federal law and under the mandate of the Environmental Protection Agency (EPA), the designation of a 
Superfund site requires the responsible party, in this case US Navy, to clean up the hazardous area. However, this decontamination process is slow and the local government has no decisionmaking capacity or input. Likewise, the FWS lacks the capacity or the authoritative power to accelerate the cleanup process, even while they do collaborate with the US Navy. According to the FWS, because of the threat these areas pose to safety and health, large parts of the NWR are closed to the public and the Service currently implements no management practices until decontamination is completed (USFWS, 2007) (Figure 2). Areas that are open to the public are accompanied by a series of restrictions, such as limited visitation hours and rules on certain activities including crab or shell gathering (Davis, Hayes-Conroy \& Jones, 2007).

Figure 2 Map depicting region VNWR encompasses and areas closed off to the public (Source: USFWS, 2007)

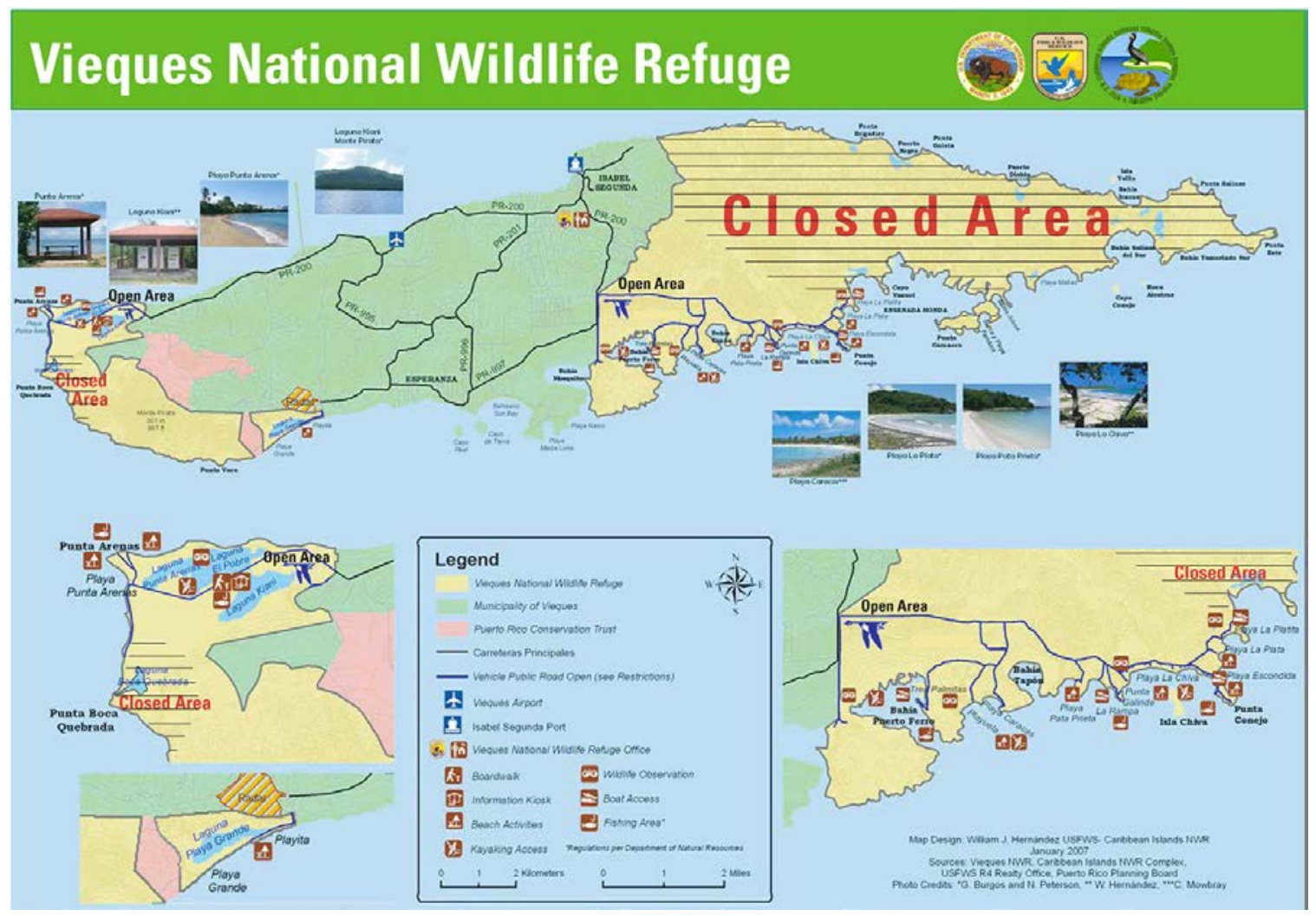


As a consequence, local resentment towards the federal government seems to still exist. According to McCaffrey (2008), the resentment shifted from US Navy to the FWS because residents view the FWS as an extension of restrictions and absolute control over the land established by the Navy. During interviews of 10 households in the study by McCaffrey (2006), resentment towards the FWS and VNWR was expressed by some respondents, along with an attitude of indifference by others. In news articles dating from 2003-2006, and more recently, 2013 (e.g., CBS, El Nuevo Día), a perception of resistance to the FWS was portrayed. Furthermore, animosity towards FWS is expressed by individuals' disregard to regulations such as trespassing - an issue brought forward by the Vieques NWR management during 2005. However, there are no comprehensive studies that have examined the perception of overall Vieques' residents toward the NWR and the FWS. The present study proposes to examine the overall public perception from household surveys. In addition, the investigation will evaluate the perceptions of the main stakeholder groups through key informant interviews.

\section{Research Questions}

The goal of my research is to describe the perceptions and attitudes of local residents of Vieques toward the National Wildlife Refuge (NWR). Conflicts that may arise from these perceptions will also be elucidated to help make management recommendations. The specific objectives are to:

1) assess overall perceptions and attitudes of residents of Vieques towards the NWR, 2) assess perceptions and attitudes towards the Vieques NWR in relation to socio-economic and demographic factors, 3) determine the local community’s level of knowledge in regards to the Vieques NWR, and 4) identify enforcement and compliance issues that may arise from local perceptions. 
II. QUANTITATIVE ANALYSIS BY HOUSEHOLD SURVEYS: Evaluating the Attitudes and Level of Knowledge of Residents towards the Vieques National Wildlife Refuge.

\section{Introduction}

The concept of protecting natural or semi-natural areas has been around for thousands of years, with examples such as royal hunting reserves as early as 700 B.C. (Runte, 1997) or ancient sacred groves in India dating back to 1500-500 B.C. (Ramakrishnan, 1996 as cited in Briggs, 2009). However, in the recent past strict forms of conservation marginalized many rural people dependent on local natural resources (e.g. Sharma, 2013 \& Rajagopalan; Vedeld, Jumane, Wapalila, \& Songorwa, 2012). The inaccessibility to natural resources often undermined conservation goals by resulting in growing tensions within park-people relations, and ultimately drove a global shift in protected areas management along with associated research (Heinen, 2010). In the realm of social science research focused on conservation, many studies suggest that it is essential to address local people’s perceptions in the management of conservation areas (e.g., Torn et al. 2008; Szell \& Hallett, 2013). Negative perceptions can potentially create conflicts in protected areas management while more positive perceptions may be beneficial in attaining conservation goals. The understanding of social and economic factors regarding these perceptions may also be important to creating and following effective conservation plans in order to better mitigate negative or false beliefs.

In the United States one type of protected areas designation is a National Wildlife Refuge (NWR), which is managed by the US Fish and Wildlife Service (USFWS). There are over 560 units that form part of the NWR system. The refuge system follows a dominant use policy where the primary goal is related to conservation, management, and restoration of wildlife and related resources (Fischman, 2002). Meanwhile, secondary uses such as recreation can exist, so long as they do not compromise primary goals. In general, secondary uses commonly occur in wildlife refuges that relate to traditional, cultural, recreational and/or economic activities. Therefore, it is 
important to understand social dimensions of NWRs including these secondary uses despite not being the Refuges' main goal as it can affect management and conservation goals.

Another important factor to consider is an incipient type of NWR, which has been referred to in various publications (e.g. Havlick, 2007, 2011, 2014; Hourdequin \& Havlick, 2011) as M2W refuges. These NWRs are established on former military lands (e.g., military bases, weapons depots, and sites of military training) that have been decommissioned and reclassified. These sites are unique and important because of the paradox they present and its implications to management and conservation practices. As a consequence of former military activities, these sites can contain both high biodiversity areas and high contamination loads. The incongruence is due to a characteristic pattern presented by these sites: a heavily impacted core, surrounded by areas that were essentially sheltered from anthropogenic disturbances because they served as buffer zones and access was significantly restricted (Havlick, 2011).

The idea of including a social research agenda in protected area management can be applied to M2W refuges. Most of these sites face unique health and safety hazards to both the public and the environment when compared to traditional NWRs. These hazards can lead to restricted access, management limitations and diverse public opinions. In addition, public perception towards these protected areas many be influenced by social, economic, and political issues related to the M2W conversion. According to Havlick (2007), there are currently twentyone M2W refuges in the US and its territories. One example that received noteworthy international news coverage during the end of its military occupation is the Vieques National Wildlife Refuge (VNWR). For some residents of Vieques, the FWS became the focus for local resentment because it is viewed as an extension of restrictions and absolute control over the land established by the navy (McCaffrey, 2008). Broadly, all protected areas must deal with parkpeople relations and perceptions of local residents. However, in certain ways M2W refuge 
officials must deal with unique types of perceptions because of the complexities of issues that relate to theses sites, as one can see with the case of the VNWR.

Vieques is an island municipality that forms part of the Commonwealth of Puerto Rico, located just seven miles off the southeast coast of Puerto Rico's mainland. The island's recent history is filled with environmental, health and social conflicts revolving around the presence of the United States (US) Navy during 60 years. The US government expropriated nearly threequarters of Vieques in the 1940s, displacing local residents from their homes for the establishment of a base and training facility (Baver, 2012). Residents of the island were exposed to the effects of naval training conducted from 1941 to 2003 (McCaffrey, 2006). Viequenses and fellow mainland citizens opposed military occupation and struggled for the cessation of military activities along with the reclaiming of their land. In 2003, the US Navy retreated from Vieques, however only 4,250 acres of the previously occupied land was transferred to the Municipality of Vieques and another 800 acres to the Puerto Rico Conservation Trust (Baver, 2012). The remaining 17,723 acres was transferred to the Fish and Wildlife Service (FWS), for the creation and management of the Vieques National Wildlife Refuge (NWR) (Baver, 2012). Therefore leading to an incomplete fulfillment of Viequenses’ aspirations during their struggle, which included the recovery of the people’s previously owned land.

After the cessation of military activities over a decade ago, there is still a legacy of contamination inherited by US Navy occupation because of warfare training and related activities that released hazardous substances into the environment (McCaffrey, 2008). Furthermore, the unexploded ordnance left behind poses further health and safety issues (McCaffrey, 2006). As a result of these hazards several areas on and around Vieques were designated as Superfund sites and listed as national priority (McCaffrey, 2006; Baver, 2006). As required by US Federal law and under the mandate of the EPA, the designation of a Superfund site requires the responsible party (in this case US Navy), to decontaminate the hazardous area. However, the process is slow 
and local government has no decision-making capacity or input. Likewise, the FWS lacks the capacity or the authoritative power to accelerate the cleanup process even while they do collaborate with the US Navy, which is in charge of decontamination activities. According to the FWS, because of the threat these areas pose to safety and health, large parts of the NWR are closed to the public and the FWS currently implements no management practices until decontamination is complete (Fish and Wildlife Service, 2007). Additionally, areas that are open to public access are accompanied by a series of restrictions, such as visitation hours limited to the daytime (October 1 to March 31: 6:00 am - 6:30 pm and April 1 to September 30: 6:00 am - 7:30 pm) or strict rules on certain activities such as crab or shell gathering (Davis, Hayes-Conroy \& Jones, 2007).

Although the local communities' attitudes and involvement seem to be an important factor in protected areas management, they are not always taken into consideration. Protected areas are still set aside in developing countries without a priori knowledge or input from local communities and, in too many places, local communities are marginalized (Heinen, 2010). In a parallel situation, the Vieques NWR was designated under Congressional law without involvement or consultation of local communities, the municipal government, or the Government of the Commonwealth of Puerto Rico. There was also no consideration of the socio-economic conflicts that would emerge from this action.

Protected areas such as NWRs and their associated government agencies have been historically underfunded and understaffed, as is the case of Vieques NWR, which has only 12 staff members. Thus, community involvement is essential for the rules and regulations instituted by managers to be effectively followed and enforced (Tissot et al., 2009). However, in the past decades the people of Vieques opposed the federal government because of the Naval occupation. Furthermore, the issue of trespassing within restricted areas was brought forth by FWS since 2005, revealing a lack of compliance with the established regulations. Not surprisingly, for some 
residents the FWS has become the focus for local resentment because they view the FWS as an extension of restrictions and absolute control over the land established by the US Navy (McCaffrey, 2008). During the interview of 10 households in the study by McCaffrey (2006), both resentment and indifference to the VNWR and its' regulations were expressed. In news articles dating from 2003-2006, and more recently, in 2013 (e.g., CBS, El Nuevo Día), there is a perception of resistance to the FWS. However, there have been no studies conducted to make an overall assessment of Vieques residents in regards to their views towards the NWR and the FWS. The current investigation proposes to complete an assessment of public perceptions from household surveys.

\subsection{Research Goals and Objectives}

The goal of this research is to determine the perceptions and attitudes of local residents of Vieques toward the National Wildlife Refuge (NWR). Conflicts that may arise from these perceptions will also be elucidated to help make management recommendations. The specific objectives are to: 1) assess overall perceptions and attitudes of residents of Vieques towards the NWR, 2) assess perceptions and attitudes towards the Vieques NWR in relation to socioeconomic and demographic factors, 3) determine the local community’s level of knowledge in regards to the Vieques NWR, and 4) identify enforcement and compliance issues that may arise from local perceptions.

\subsection{Site Description}

The study was conducted in the island municipality of Vieques that forms part of the Commonwealth of Puerto Rico, an unincorporated territory of the United States of America. The island is located just seven miles off the southeast coast of Puerto Rico’s main island on the geographical coordinates $18^{\circ} 7^{\prime} 29.8956 " \mathrm{~N}, 6^{\circ} 26^{\prime} 31.6428^{\prime \prime} \mathrm{W}$. Vieques has a land area of 
about $127.4 \mathrm{~km} 2$, with a length of approximately $33 \mathrm{~km}$ and width of $7 \mathrm{~km}$ (Bauer et. al, 2008). Over half of the island is designated as a National Wildlife Refuge with the residents and tourist residing in the central part of the island. The entire VNWR accounts for 17,769 acres of land, with 14,623 acres in the eastern side and 3,100 acres in the western side. It is the largest Refuge in the Caribbean Islands NWR Complex. In the eastern portion of the VNWR, most of the access is restricted, except for several beaches, while the superficial decontamination by the Navy is in process. In addition, 900 acres of land are designated as Wilderness, thus impeding access to the general public for perpetuity. According to the 2010 Census Bureau, the island had 9,301 residents and 3,666 households. The economy of the island has been increasingly reliant on tourism both directly and indirectly, with thousands of tourist visiting yearly. However, Vieques is still one of the poorest municipalities of PR. It has an unemployment rate of $10.1 \%$ and approximately $43.2 \%$ of the population lives below the poverty level according to the American Community Survey 5-Year Estimates reported by the U.S. Census Bureau in 2013. Overall, Vieques is a rural island municipality.

The island and surrounding water has a warm and humid climate characteristic of a tropical marine environment (Bauer et. al, 2008). Temperature is relatively constant throughout the year, with highs and lows ranging between $29-32^{\circ} \mathrm{C}$ and $19-22^{\circ} \mathrm{C}$. Meanwhile, precipitation is characterized by seasonal (wet/dry season) and spatial fluctuations, with occasional tropical cyclones. The spatial distribution of rainfall across the island varies with a general gradient in which precipitation increases from the east to west as a result of differences in elevation. Rainfall and elevation in turn reflects upon the distribution of primary vegetation types. Furthermore, vegetation is also in different stages of succession.

Vieques falls within the subtropical dry forest and subtropical moist forest life zones (USFWS, 2008). There are various vegetation communities including beach, coastal strand forest, mangrove, subtropical dry forest and shrub, mixed evergreen-deciduous forest and grassland. The 
variety of terrestrial and surrounding aquatic ecosystems in the VNWR support native, endemic, migratory, rare and protected species of which sixteen are federally listed. The surrounding waters of Vieques are characterized by a variety of estuarine and marine habitats, most notably large expanse of seagrass beds, coral reefs and three bioluminescent bay ecosystems.

Bioluminescent bays are rare ecosystems characterized by the high density of the dinoflagellate Pyrodinium bahamense var. bahamense, which react to movement in the water, producing the bioluminescent effect. One of the world's brightest bays, Puerto Mosquito, is found off the Puerto Rican island of Vieques (O’Connell et al, 2007).

The sandy beaches of the island provide nesting grounds for globally threatened Chelonia mydas (Green Turtle), Eretmochelys imbricata (Hawksbill), and Dermochelys coracea (Leatherback) sea turtles. The critically endangered Acropora cerviconis (Staghorn Coral) and Acropora palmate (Elkhorn Coral) are both found in the reefs surrounding Vieques along with over 200 fish species. Meanwhile, there are over 170 bird species including both migratory and resident species such as the Melanerpes portoricensis (Puerto Rican woodpecker), Sterna dougallii (Roseate Tern), and the Falco peregrinus (Peregrine falcon). In coastal regions the Cardisoma guanhumi (blue land crab) can be found, which is a species of cultural and economic importance for the people of Vieques. In terms of plant species, according to the USFWS (2007), there are 27 rare and 5 federally listed plant species. This includes Eugenia woodburyana (Woodbury’s Stopper), Goetzea elegans (Mata Buey), Calyptranthes thomasiana (Thomas’ Lidflower), Chamaecrista glandulosa var. mirabilis (Puerto Rico Senna) and Stahlia monosperma (Cóbana Negra). Overall, the biodiversity in the VNWR provides an opportunity for the conservation of ecosystems unique to the tropics, in addition to a base for sustainable socioeconomic activities such as ecotourism and nature based recreation. 


\section{Methods}

\subsection{Data Collection}

Previous studies (e.g., Heinen, 2010; Shrivastava \& Heinen, 2007; Moorman, 2006; Baptiste \& Nodenstam, 2009; Sesabo et al., 2006) have shown the relevance of social science tools in acquiring information regarding local people’s perceptions, attitudes, level of knowledge, natural resource use and other such issues to improve PA management. In particular, semistructured questionnaire surveys have been used by a variety of researchers (Heinen, 1993; Fiallo \& Jacobson, 1995; Sah \& Heinen, 2001; Heinen \& Shrivastava, 2009;) to study relations between PAs and people. Therefore, in the present study a semi-structured survey was adapted from previous studies (e.g., Roque, 2011; Baral \& Heinen, 2007; USFWS, 2007). The survey included basic demographic questions regarding age, household number, occupation, birthplace, and level of education that were cross-classified with questions concerning attitudes, awareness, resource use, etc. It also asks several other close-ended questions such as time living in Vieques to identify differences that may arise when comparing long-term residents' perception to short term residents' perception of the NWR (Appendix 1). A series of combined open-ended and closedended question evaluated the resident's knowledge of the NWR and their attitudes towards it. These questions provided information not only on the residents' perception but also demographic and other characteristics that may be influencing the residents’ perceptions and attitudes. Some questions inquired about the previous military presence and the current NWR with regards to health, economic, and social well-being. Participants were also asked about the activities they conducted in the refuge to acquire an understanding of land and resource use.

A total of 235 semi-structure household surveys were conducted between July 2014 and January 2015, which accounts for $6.41 \%$ of total households an acceptable statistically significant sample size (Turner, 2003). Random sampling was done in the two main towns (Isabel II \& Esperanza) and all the residential areas of the island as per Roque (2011) study in Puerto 
Morelos, Mexico. The survey was conducted in a door-to-door manner to insure representation of all sectors of the population. In addition, survey respondents were approached in the town plaza, at shops, restaurants, the boardwalk, ferry dock, during festivals and even at the beach. Locations were visited at different times of the day, as well as weekdays and weekends to guarantee adequate sampling representation. Furthermore, public space sampling was also done for safety reasons.

\subsection{Data analysis}

The quantitative data were analyzed to identify the presence of any common patterns and relationships using the Statistical Package for Social Scientist (SPSS) version 22. To facilitate the statistical analysis, an attitude score was calculated for each respondent on the basis of replies to nine questions. For example a question asking if the respondent is in favor of the rules and regulations in the VNWR would receive a numerical value of 1 for a YES answer, 0 for a NO response and a value of 0.5 for NEUTRAL or DO NOT KNOW (Table 1 ). The values of all nine questions were summed to give a cumulative attitude score. Since in some cases not all respondents answered all nine questions, the sum of individual values was divided by total number of questions answered to acquire a standardized attitude score. The standardized attitude score was then analyzed against gender, age, level of education, occupation and time living in Vieques among other variables. The same was done for questions related to level of knowledge in order to calculate an awareness score. Individual responses for the questions were assigned a point value, which was then added up and divided by the highest possible point value to produce a standardized awareness score (AwareStd). Statistical test included mean comparisons with oneway analysis of variance (ANOVA), Kruskal Wallis, and Mann-Whitney test. When choosing the statistical tested to be used, the data were examined to determine if they met the assumptions of normal distribution and homogeneity of variance using the Shapiro-Wilk test and Levene's test. If the data were not normally distributed but did have homogeneity of variance, it was transformed 
using natural $\log (\ln )$ and square root (sqrt) in an attempt to approach normal distribution.

However, if this failed or the data did not have homogeneity of variance as well, then non-

parametric tests were used. Effects of age and time living in Vieques on people's perception and attitude were analyzed using simple linear regression and multiple hierarchal regressions.

Table 1 Summary of attitude questions, variable name, and numerical values per response. For each question the respondent could acquire a score that ranged from $0-1$. The final standardized attitude score can range from $0-9$.

\begin{tabular}{|c|c|c|}
\hline Attitude Questions & Attitude Variable Name & Value Per Response \\
\hline Are you in favor of the rules and regulations? & AttitudeRR & $\begin{array}{c}\text { Yes }=1 \\
\text { No }=0 \\
\text { Some }=0.5\end{array}$ \\
\hline Did you agree with the creation of the VNWR? & AgreeNWR & $\begin{array}{c}\text { Yes }=1 \\
\text { No }=0 \\
\text { Neutral }=0.5\end{array}$ \\
\hline $\begin{array}{l}\text { The refuge personnel are professional and } \\
\text { courteous. }\end{array}$ & EmployesAttitude & $\begin{array}{c}\text { Agree }=1 \\
\text { Disagree }=0 \\
\text { Neutral }=0.5 \\
\text { Ignorant }=0.5\end{array}$ \\
\hline In general the refuge is well managed. & RefugeMgt & $\begin{array}{c}\text { Agree }=1 \\
\text { Disagree }=0 \\
\text { Neutral }=0.5 \\
\text { Ignorant }=0.5\end{array}$ \\
\hline $\begin{array}{l}\text { In general, could you say you are happy that the } \\
\text { former Naval lands in Vieques are now a } \\
\text { NWR? }\end{array}$ & FavorNWR & $\begin{array}{c}\text { Yes }=1 \\
\text { No }=0 \\
\text { Neutral }=0.5\end{array}$ \\
\hline $\begin{array}{l}\text { Would you and your family prefer the NWR } \\
\text { lands to remain under the control of the US } \\
\text { federal government (FWS) or would you like } \\
\text { the land to be ceded? }\end{array}$ & LandControl & $\begin{array}{c}\text { Feds }=1 \\
\text { Ceded }=0 \\
\text { None }=0.5 \\
\text { Other }=0\end{array}$ \\
\hline $\begin{array}{l}\text { In the case of ceding the lands to another } \\
\text { agency or institution, should the lands remain } \\
\text { as a protected area or used another way? }\end{array}$ & LandDesig & $\begin{array}{c}\text { PA }=1 \\
\text { Another }=0 \\
\text { Both }=0.5 \\
\text { Other }=0.5\end{array}$ \\
\hline Are there advantages to having the VNWR? & AdvNRW & $\begin{array}{c}\text { Yes }=1 \\
\text { No }=0 \\
\text { Neutral }=0.5\end{array}$ \\
\hline Are there disadvantages to having the VNWR? & DisadvNRW & $\begin{array}{c}\text { Yes }=0 \\
\text { No }=1 \\
\text { Neutral }=0.5\end{array}$ \\
\hline
\end{tabular}




\section{Results}

\subsection{Descriptive statistics for Independent Variables}

Among the respondents surveyed there was almost an even distribution between genders with $45.5 \%(n=107)$ females and 54.5\% $(n=128)$ males. The mean age was $48.2( \pm 17.0)$ (Table 2). The majority of people (72.8\%) were born in Vieques, while $23 \%$ had migrated from either mainland PR or USA (Table 3). Their mean time living in Vieques was 37.8 years $( \pm 21.9)$, although values ranged from $>1$ year to 84 years. The mean number of household members was 3 individuals, but ranged from 1 to 12 individuals. Respondents’ occupations were listed within seven categories. A large number of respondents (43.4\%) were not working at the time surveyed; this included the retired, housewife, and unemployed categories (Table 3). Tourism related occupations accounted for $17.9 \%$ of respondents. Meanwhile, occupations grouped into Other category (18.7\%) included health care practitioners, stylists, clerks, heavy equipment operators, security guards, maintenance employees, business owners, and students. Highest level of education obtained by respondents, was divided into five categories: LessHS (less than high school degree or equivalent), HS (high school degree or equivalent), SOME (some college, an associate’s degree, or technical/vocational training), BA (bachelor’s degree) and GradDegree (Graduate degree). Most individuals fell in HS (30.6\%) or SOME (31.1\%) category, with very few having a higher education degree (Table 3).

On broad topics, residents surveyed were asked about the activities that they practiced in the refuge, their involvement in the protest against the navy, and about violations to refuge regulations. The responses for activities within the Refuge were classified as Consumptive, Nonconsumptive and No-use. Consumptive use was regarded as anything that resulted in extraction of natural resources from the refuge, such as fishing, land crabbing, or collecting sea snails, and non-consumptive referred to activities such as hiking, water sports, or day trips to the beach that did not cause resource removal. Results showed that $54.1 \%$ of participants use the refuge for non- 
consumptive activities, $35.3 \%$ for consumptive purposes, and $10.6 \%$ no use. Before the creation of this M2W refuge, there were a series of protest and manifestations against the presence of the US Navy. Only 38.5\% of respondents affirmed to having participated in such protests. Finally, individuals were also asked if they or any member of their household had ever received a fine or warning within the VNWR since its inception. In this case $75.4 \%$ of participants replied no and $24.6 \%$ replied yes.

Table 2 Descriptive statistics for demographic variables. Includes independent variables of age, household numbers and time (years) that respondent has lived in Vieques.

\begin{tabular}{lcccc} 
Demographic Variables & Minimum Value & Maximum Value & Mean & Standard Deviation \\
\hline Age & 18 & 85 & 48.21 & 17.025 \\
Time in Vieques & 0 & 84 & 37.79 & 21.878 \\
Adults in Household & 1 & 7 & 2.3 & 1.19 \\
Minors in Household & 0 & 5 & 0.69 & 1.132 \\
Total Household & 1 & 12 & 2.99 & 1.81 \\
\hline
\end{tabular}


Table 3 Frequencies for independent demographic variables.

\begin{tabular}{llcc} 
Demographic Variables & Category & Frequency & Percent \\
\hline \multirow{3}{*}{ Gender } & Female & 107 & 45.5 \\
& Male & 128 & 54.5 \\
Birthplace & Vieques & 171 & 72.8 \\
& Mainland, PR & 27 & 11.5 \\
& USA & 27 & 11.5 \\
& Other & 9 & 3.8 \\
& Missing & 1 & 0.4 \\
& & & \\
Occupation & Retired & 45 & 19.1 \\
& Tourism & 42 & 17.9 \\
& Housewife & 33 & 14 \\
& Government & 28 & 11.9 \\
& Self & 28 & 11.9 \\
& Unemployed & 15 & 6.4 \\
& Other & 44 & 18.7 \\
& LessHS & & 20 \\
& HS & 47 & 30.6 \\
& Some & 72 & 31.1 \\
BA & 73 & 14 \\
& GradDegree & 33 & 4.3 \\
& & 10 & \\
\hline
\end{tabular}

\subsection{Attitude towards Vieques National Wildlife Refuge}

One of the main research questions was to assess the overall perception of Vieques residents towards the NWR. The mean standardized attitude score (AtdScoreStd) across all respondents fell between $0-1$, with a mean value of 0.58 and standard deviation of 0.28 Thus, there is no strong inclination towards a positive or negative attitude in regards to the VNWR. While analyzing the responses to specific questions (Table 4), we found that $57.4 \%$ of respondents agreed with the creation of the VNWR and 51.7\% were happy that the former Naval lands are now a NWR. Two thirds of respondents (68.9\%) think there are advantages from having 
the NWR in Vieques. Meanwhile, 55.3\% also agreed that there were disadvantages. The reason for the overlap in these results is that $33.48 \%$ of respondents consider that there were both advantages and disadvantages due to the NWR. Among the frequent responses to the follow up open-ended questions, it was found that participants considered conservation an advantage, meanwhile access and resources restrictions, disadvantages. Almost half of the residents surveyed (48.1\%) wanted the refuge lands to remain as a protected area, but not necessarily under the control of the federal government. One-third (34.9\%) of respondents wanted the land to remain under the control of the FWS. When looking at how individuals viewed employees and refuge management, less than half (39.6\% and 37.0\% respectively) agreed that the employees were courteous and professional or that the refuge was well managed. Finally, when asked about their attitudes toward the rules and regulations of the refuge, 60 (25.5\%) participants could not respond because they were unfamiliar with the rules and regulations (Table 4). Of the respondents that did know at least some of the rules and regulations, 26\% agreed with them and 20\% disagreed. Most respondents 53.7\% fell in-between, only agreeing with some rules while others displeased them. Among the most common reasons for expressing discontent were the restrictive regulations regarding access to NWR. In addition, a secondary reason for many of them was the limitation on resource extraction. The limitations on resources most frequently mentioned were fishing regulations, restrictions on land crabs, sea snails, hermit crabs, and collection of coconuts. An interesting note is that although many individuals do not fish occupationally, they do so to for personal consumption to alleviate high food cost. 
Table 4 Frequency and percentages for variables used to calculate attitude score.

\begin{tabular}{|c|c|c|c|}
\hline Attitude Variables & Response & Frequency & Percent \\
\hline \multirow[t]{4}{*}{ AttitudeRR } & No & 35 & 14.9 \\
\hline & Yes & 94 & 19.6 \\
\hline & Some & 46 & 40.0 \\
\hline & Not Applicable & 60 & 25.5 \\
\hline \multirow[t]{4}{*}{ AgreeNWR } & No & 63 & 28.3 \\
\hline & Yes & 135 & 57.4 \\
\hline & Neutral & 25 & 10.6 \\
\hline & Missing & 12 & 5.1 \\
\hline \multirow{5}{*}{ EmployeAttitude } & Agree & 93 & 39.6 \\
\hline & Disagree & 30 & 12.8 \\
\hline & Ignorant & 66 & 28.1 \\
\hline & Neutral & 44 & 18.7 \\
\hline & Missing & 2 & .9 \\
\hline \multirow[t]{5}{*}{ RefugeMgnt } & Agree & 87 & 37.0 \\
\hline & Disagree & 33 & 14.0 \\
\hline & Ignorant & 69 & 29.4 \\
\hline & Neutral & 43 & 18.3 \\
\hline & Missing & 3 & 1.3 \\
\hline \multirow[t]{5}{*}{ LandControl } & Cede & 108 & 46.0 \\
\hline & Feds & 82 & 34.9 \\
\hline & None & 35 & 14.9 \\
\hline & Other & 9 & 3.8 \\
\hline & Missing & 1 & .4 \\
\hline \multirow[t]{5}{*}{ CedePA } & Another & 61 & 26.0 \\
\hline & Both & 39 & 16.6 \\
\hline & Other & 14 & 6.0 \\
\hline & PA & 113 & 48.1 \\
\hline & Missing & 8 & 3.4 \\
\hline \multirow[t]{4}{*}{ FavorNWR } & No & 72 & 30.6 \\
\hline & Yes & 121 & 51.5 \\
\hline & Neutral & 38 & 16.2 \\
\hline & Missing & 4 & 1.7 \\
\hline \multirow[t]{3}{*}{$A d v N R W$} & Neutral & 24 & 10.2 \\
\hline & No & 49 & 20.9 \\
\hline & Yes & 162 & 68.9 \\
\hline \multirow[t]{4}{*}{ DisadvNRW } & Neutral & 22 & 9.4 \\
\hline & No & 81 & 34.5 \\
\hline & Yes & 130 & 55.3 \\
\hline & Missing & 2 & .9 \\
\hline
\end{tabular}


There was no significant difference in mean attitude scores between male and female respondents (Mann-Whitney Test: $\mathrm{U}=6354$, p-value $=0.332$ ). Level of education also had no significant effect on attitude scores (K-W test: $\mathrm{H}(3)=4.611, p=.203)$. When looking at occupation there was also no significant difference in attitude $[\mathrm{H}(6)=11.169, p=.083]$ for the categories used. However, based on responses to a follow up question inquiring whether the participants’ occupation depended directly or indirectly on the tourism sector, results show that those affected by tourism had a significantly more positive attitude about the VNWR than those who did not (Mann Whitney test: U=5172, $p=.037$ ). Similarly, birthplace also had effects on respondents' attitude scores $[\mathrm{H}(3)=24.641, p=.000]$. For instance, respondents born in the USA had a more positive attitude about the VNWR than those born in Vieques. When the analysis was restricted to test the difference between those born in Vieques and elsewhere, the people born in Vieques (0.53) had significantly lower attitude score than those who moved to the island later (.72) (Mann-Whitney test: $\mathrm{U}=7507.5, \mathrm{p}=.000$ ) (Figure 3).

Figure 3 Mean attitude score of respondents based on birthplace.

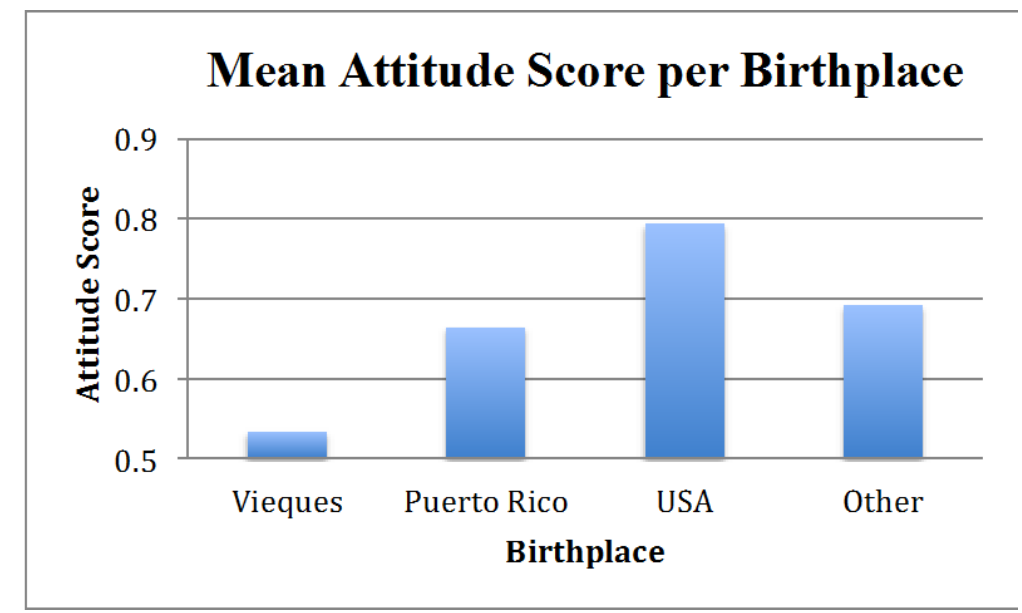


The variable age had an effect on mean attitude scores of respondents when analyzed in the intervals of $18-39,40-59$, and $\geq 60$ years old [K-W test: $\mathrm{H}(2)=7.382, p=.025]$ (Figure 4). The 18-39 interval had a significantly higher attitude score than the 40-59 age interval. When age was grouped into intervals of roughly 10 years, it also yielded statistically significant results [K-W test: $H(5)=13.187, p=.022]$ (Figure 4). The 18-29 year olds had a higher attitude score than individuals 60-69 years old. Likewise, time in Vieques [K-W test: $\mathrm{H}(4)=24.788, p=.000]$ had an effect on attitude (Figure 5). Those who had lived between 0-10 years in Vieques had a significantly higher attitude score than those that had lived 30 and above years. A noteworthy observation is that those having lived in Vieques for $\geq 71$ did not have a statistically significant difference in attitude score with the 0-10 year group or any other group. The oldest respondents, or those who have lived longest in Vieques seem to slightly increase in attitude score, although that increase was not statistically significant.

Figure 4 Mean attitude score of respondents per age in 3 intervals of approximately 20-years and 6 intervals of approximately 10-year

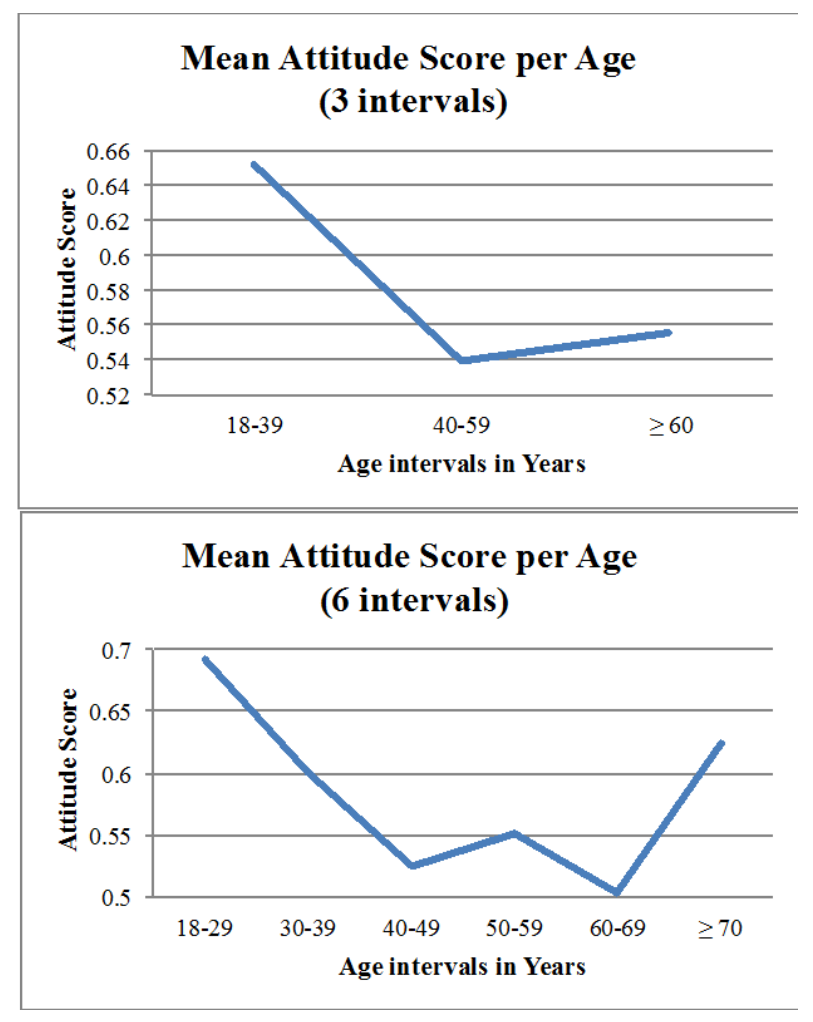


Figure 5 Mean attitude score for time living in Vieques divided into 10-year interval categories.

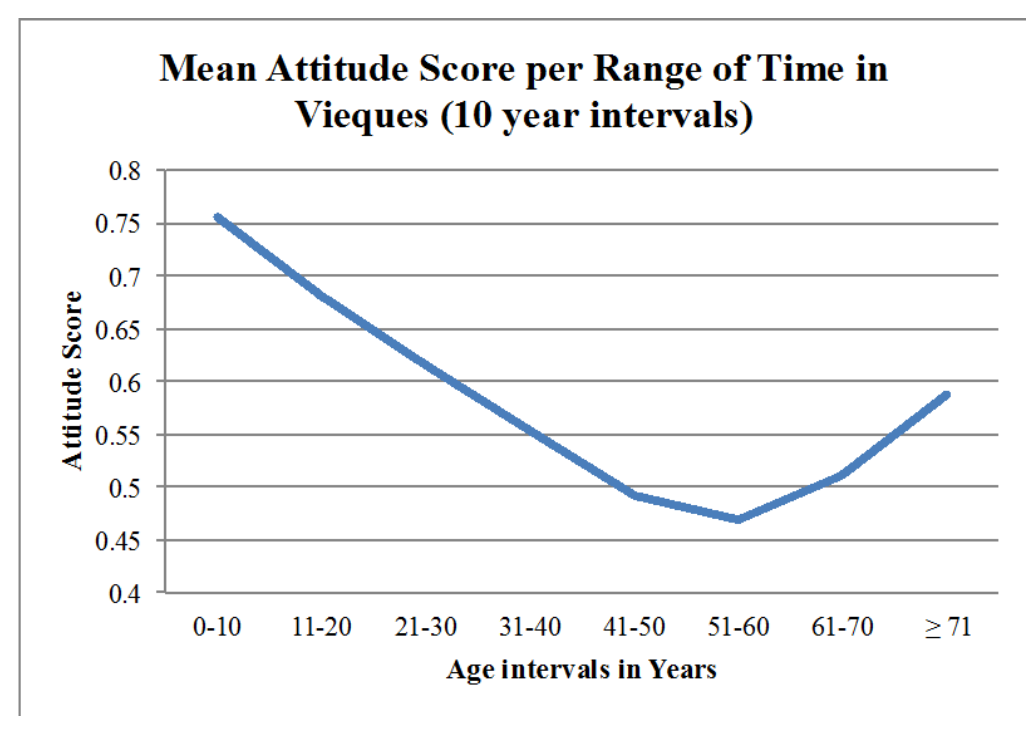

When looking at the mean attitude score plots for age and time in Vieques in the form of categorical data, it is evident that there might be a pattern emerging. Therefore a quadratic fit through hierarchal multiple regressions was preformed on the data in continuous form to test for the presence of nonlinear effects. For the independent variable age, the test yielded statistically significant results $\left(\mathrm{F}_{2,232}=5.778, p=.004\right)$. The standard coefficient revealed that although the linear regression is negative $(b=-1.077)$, the non-linear part of the model is positive $(\mathrm{b}=.944)$.Thus correlating to the K-W test results. However, it is important to note that age only accounts for $4.7 \%$ of variability of attitude score $\left(R^{2}=.047\right)$. When running the same analysis on the independent variable time in Vieques this was statistically significant $\left(F_{2,232}=13.079\right.$, $p=.000)$, although only accounting for $10.1 \%$ of variability $\left(R^{2}=.101\right)$. The standard coefficient revealed that although the linear regression is negative $(b=-0.833)$, the non-linear part of the model is positive $(b=.587)$. Therefore, this correlates again with the mean plots and $\mathrm{K}-\mathrm{W}$ test results. 
Respondents conducting three different use patterns within the NWR (non-consumptive, consumptive, and no-use) did not significantly differ in mean attitude scores (K-W test: $\mathrm{H}(2)=2.885, p=.236)$. Another aspect considered was looking at how involvement in the protest against the Navy may relate to the residents attitude. Statistical analysis showed that participation in the anti-navy protest effected attitude (Mann-Whitney test: $\mathrm{U}=9403.5, p<0.001$ ). Respondents who participated in such protest obtained a lower attitude scores than those who did not. Similarly, those surveyed who had receiving a warning or fine in the VNWR, had a lower attitude score than their counterparts (Mann-Whitney test: $\mathrm{U}=6453, p=.001$ ).

\subsection{Awareness of the Vieques National Wildlife Refuge}

Another research objective I pursued was an assessment of the level of knowledge regarding the VNWR held by members of the local communities. The standardized awareness score (AwareStd) for all respondents varied between $0-1$, with a mean value of 0.486 and standard deviation of 0.239 When looking at some of the specific questions, only one fourth of respondents were familiar with the rules and regulations of the refuge, while half of the population (49.8\%) knew at least some of the rules and regulations. The remaining one fourth expressed their ignorance towards rules and regulations (Table 5). In terms of knowing or having received information about the refuge’s ecological importance, only 31.6\% of participants replied yes. On the other hand, $83.33 \%$ of respondents did agree that the refuge lands have ecological importance although not necessarily knowing why or having received any such information. When participants were asked what they considered ecologically important, their responses ranged from specific environmental functions to less informed answers demonstrating severe a lack of knowledge of basic ecology. Responses were assigned a point value depending on these responses ranging from 0-3, which was later added as part of the final AwareStd. A large frequency of responses demonstrated a lack of knowledge in the ecological importance of the 
VNWR with $41.7 \%$ attaining 0 points and $27.2 \%$ acquired a value of 1, 20\% received 2 points, and only $11.1 \%$ achieved the maximum 3 points for this question. Finally, more than half $(71.8 \%)$ of the residents received information about the health and safety issues in areas within the refuge.

It was also of interest to see if there were any correlations between the level of awareness related to the VNWR and certain independent variables regarding demographic, social, and economic factors. There was no significant difference in mean awareness scores between male and female respondents (Mann-Whitney test: $\mathrm{U}=6309.5 p=0.297$ ). However, birthplace did have a significant effect on awareness scores (K-W test: $\mathrm{H}(3)=8.348, p=0.39)$. Respondents born in the USA had more positive attitude than those born in Vieques (Figure 6). Levels of education also had a significant effect on attitude $\left[\mathrm{F}_{3,231}=15.221, \mathrm{p}<.001\right]$. For instance, respondents in the LessHS and SOME category had a lower awareness score than those in both SOME and GradDegree category (Figure 7). For occupation there was also a significant difference in awareness scores $\left[\mathrm{F}_{6,228}=5.738, \mathrm{p}<.001\right]$ for the categories used. Furthermore, when respondents were asked specifically if they worked in the tourism sector directly or indirectly, those who replied yes showed a significantly higher mean awareness score (Mann-Whitney test: $U=4652$, $p=.002)$.

Figure 6 Mean awareness score of respondents based on birthplace.

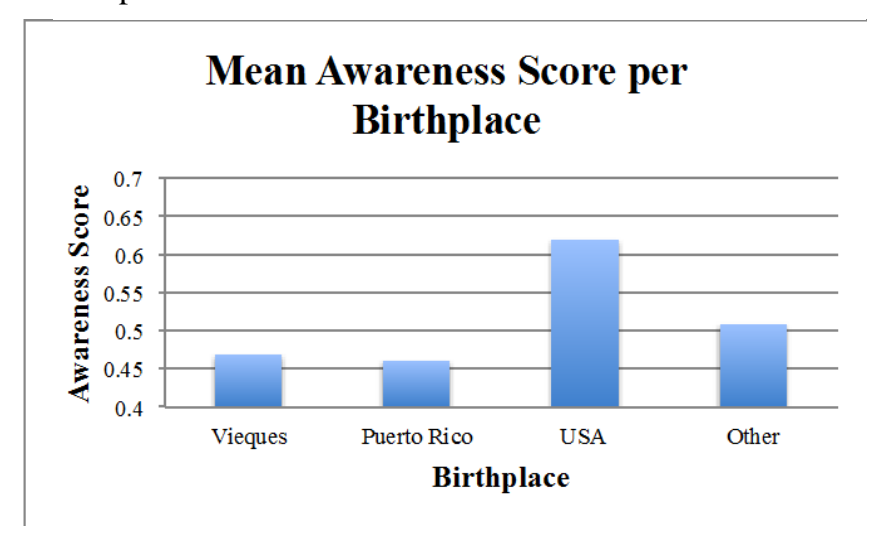


Figure 7 Mean awareness score of respondents within each of the education levels.

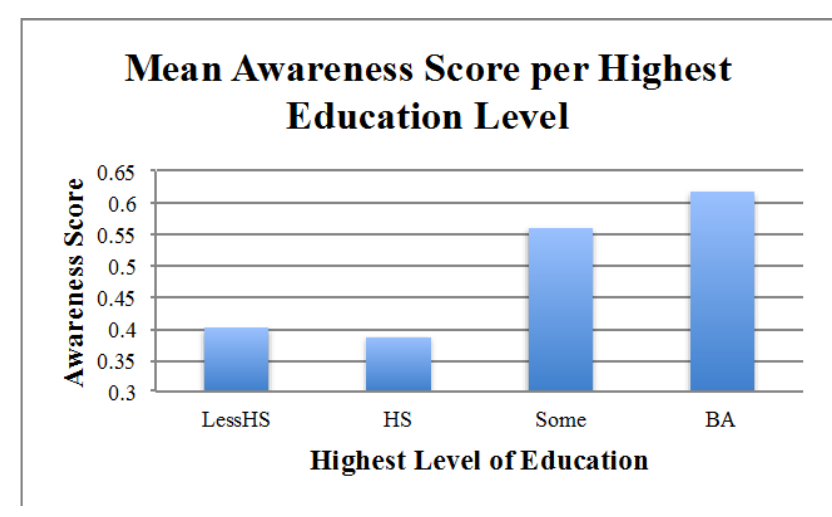

The variables age and time in Vieques were examined using various tests, in the form of continuous and categorical data. In the form of continuous data, a simple linear regression was used to see if a correlation existed between these variables and the awareness score. The regression reveals that there is a statistically significant $(p=0.003)$ correlation between age and awareness score. However the R squared value of .037 indicates there is a weak relationship for which only $3.7 \%$ of the variability of the awareness score is accounted for by the independent variable age. Furthermore, the weak correlation is negative as indicated by the standard coefficient (-0.193). The simple linear regression for time in Vieques also reveals that there is a statistically significant $(\mathrm{p}<0.0001)$ correlation between this variable and awareness score. Moreover, the standard coefficient value (-.259) conveys that this relationship is negative. Nonetheless, the R squared value $\left(R^{2}=.067\right)$ expresses that only $6.7 \%$ of variability is accounted for by the independent variable time in Vieques.

When looking at these variables as categorical rather than continuous, the data show a similar pattern. The variable age had an effect on the mean awareness scores of respondents when analyzed in intervals of roughly 10 years $\left(\mathrm{F}_{5,229}=2.716, p=.021\right)$. The 40-49 age interval had a 
higher level of awareness than that of the $\geq 70$ age group (Figure 8 ). Likewise, when time in Vieques was analyzing in 15-year intervals the results showed a statistically significant effect on awareness $\left(\mathrm{F}_{4,230}=4.126, p=.03\right)$ (Figure 9). Participants that had lived 0-15 years on the island had a significantly higher mean awareness score than those who had resided 61 or more years. On the basis of the results from the regression and mean comparison tests there is an overall negative relationship between time living in Vieques and age, with the standardized awareness score.

Figure 3 Mean awareness score for age of respondent divided into 10-year intervals.

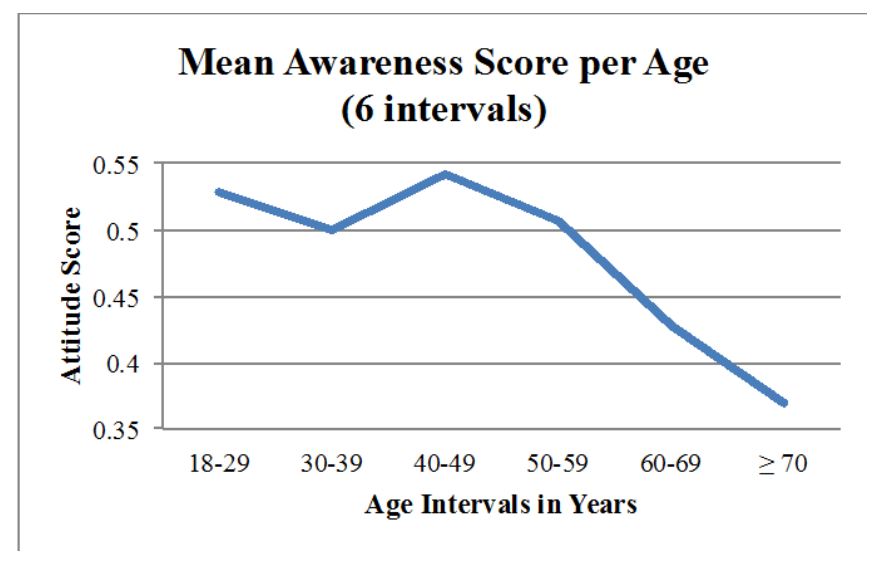

Figure 9 Mean awareness score for time survey respondents have lived in Vieques divided in 15-year interval.

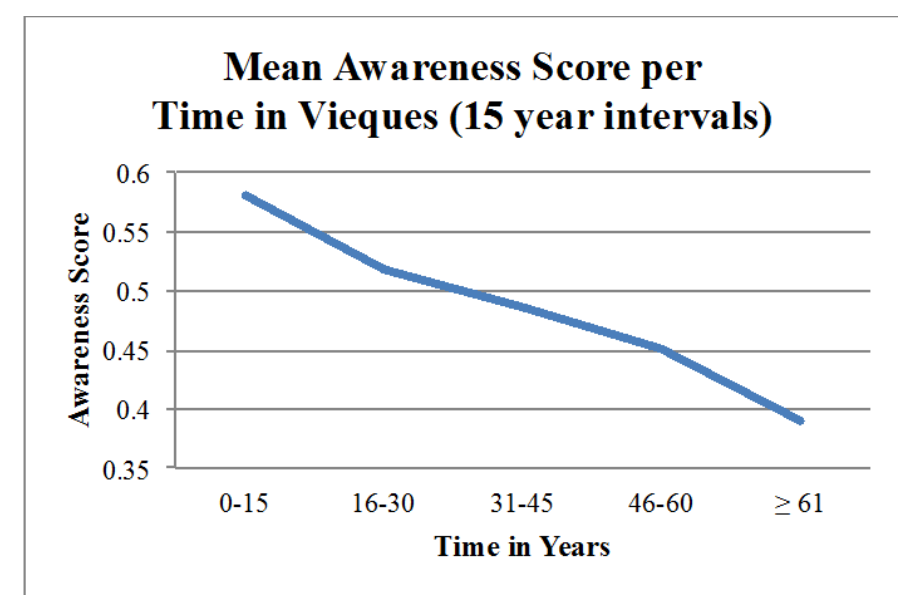


Respondents' level of awareness was affected by the types of uses $\left[F_{2,232}=4.391\right.$, $p<.013]$. Results showed that the no-use group had a significantly lower mean awareness score than both consumptive and non-consumptive groups. Similarly, participants who had receiving a warning or fine in the VNWR, had a lower awareness score than their counterparts (MannWhitney test: $\mathrm{U}=4115.0, p=.046)$. On the contrary involvement in the anti-naval protest did not affect resident's awareness (Mann-Whitney test: $\mathrm{U}=5449.0, p=.210$ ).

\section{Discussion}

\subsection{Attitude towards Vieques National Wildlife Refuge}

The perceptions and attitudes displayed by the residents of the Vieques towards the FWS and the VNWR are very complex and somewhat convoluted. There are many factors that influence the correlations and trends that are presented in the results as well as the opinions residents convey towards the wildlife refuge and agency. Significant results found during data analysis show that age, time in Vieques, involvement in the tourism sector, place of birth, awareness score, receiving fines and participating in Naval protests all influenced the attitude of individuals surveyed. There are many aspects as to why these variables may affect attitude including historical, social, and economic factors. When looking at the variables of age and time in Vieques, the same general trend is observed in the form of a weak negative correlation between the independent variables and the dependent attitude score. Furthermore, a curvilinear regression shows that there is a small curve displayed with a weak increase in attitude after a certain age or years in Vieques. Age and time in Vieques correlate because of course if you have lived your entire life in Vieques, the older you are and the more years you have been there. However, it was important to look at both variables because not all individuals surveyed have lived their entire lives in Vieques. Furthermore, the underlying reasons that could create this trend are not necessarily correlated with both factors. 
On the basis of the opened-ended responses of survey participants and conversations with refuge employees, younger survey participants are targeted for many of FWS outreach and educational programs that include activities directed towards youth that take place within the refuge, outreach in schools, and even a paid summer program. These outreach and educational programs correlate with increased attitude scores for younger respondents. In general, environmental education and awareness have been shown to influence individual's attitudes towards conservation in a positive way (e.g., Arcury, 1990; Aminrad, et al., 2013; Bradley et al., 1999). At the other end of the spectrum older individuals in retirement have also been targeted to a lesser extent by the FWS as per interview with Sandra Ortiz, the FWS outreach coordinator for the VNWR. Although this was not directly stated in the surveys, some respondents within the oldest age interval did express an indifference towards the VNWR and land use policies. These expressions along with FWS focusing on specific age groups for outreach can explain the weak negative correlation between age and attitude score, as well as the weak positive curve formed by these two variables. Although these correlations can partially translate to time in Vieques, not all individuals living less time in Vieques are necessarily young and vice versa, not all old individuals have necessarily lived long time periods on the island.

There might be other factors influencing perception in terms of the independent variable, time in Vieques and consequently in some instances, age as well. Possible reasons for the trend may be more complex than a simply increase in education and awareness. For over 50 years the US Navy occupied two thirds of Vieques. The older residents of the island born in Vieques might have lived through the expropriations or heard vivid recollections from their parents. These residents as well as those mid-age or older lived through the intensification of live firing practices during the 70s, which could have influence their perceptions towards the US federal government and in turn the FWS with the VNWR. In that period there was also an uprising against the Navy. During the surveying process and even by means of informal interviews it became evident that 
older respondents who grew up and lived during the Naval presence also remember having more liberties within the former military lands. One survey respondent 54 years of age says, “There are more restrictions now then when the Navy was here”. Another respondent 79 years old states, "We use to fish at night when the navy was here, but now its not allowed". Finally, another respondent 68 years old expressed how he would like to be able to stay at the beach overnight camping like they use to before the Navy left. Unfortunately, camping is no longer allowed since the VNWR was inaugurated.

Much like the respondents described above, other residents would have had the opportunity to camp, go fishing, or land crabbing in the former Naval grounds when military exercises were not being conducted. In addition, they would have had access to more lands than are currently accessible. Individuals might have enjoyed the traditional “corrida de jueyes” inside the lands now part of the VNWR. The cultural event occured during the peak of the land crabbing season were people would gather to watch the masses of land crabs and many would also try to trap them. All of these activities are now either prohibited or have highly regulated restrictions within the refuge. Nevertheless, respondent having lived on the island for 12 or less years when surveys were conducted, were not present when the US Naval base was in operation. Therefore, these respondents would not have been affected by conditions during that time period. Even individuals between the ages of 18-29 born in Vieques and who have lived in the island their entire lives may not have been fully conscious of the military presence and the increase in regulations. Furthermore, they would not have experienced or have been cognizant of the bombing during military exercises that as one resident recollected "would shake our home, create cracks on the walls and awaken us at night fearfully”. Now, one might think that the M2W conversion would result in a positive trend were increased attitude scores would become evident as age increases because individuals who lived through the Naval presence would be content that live-fire military practices have ended. However, it seems for some the FWS is a mere extension 
of the US Navy. Several respondents actually used the same idiom in Spanish, to refer to this, "FWS es el mismo perro con distinto collar". A direct translation being, "FWS is the same dog with a different collar.” Thus, comments like the ones mentioned previously make sense within this mind frame. Some individuals see the FWS just as an extension of the Navy; another federal government agency imposing their authority over the people of Vieques. Moreover, as part of the Navy's clean-up process, open detonations of UXOs are conducted. The controversial process is a well-known practice, while in spite of FWS's active environmental management, there is a lack of public knowledge on habitat improvements and successful restorations of areas within the former Naval site.

Nonetheless, as mentioned before, the factors affecting resident's attitudes and perceptions are very complex and contradictory hence both age and time in Vieques do not explain all of the variability within mean attitude scores. Another factor effecting mean attitude score was tourism. People who stated that they worked directly or indirectly in tourism displayed a higher mean attitude score then those who did not. The result is not surprising as, some studies (e.g., Sekhar, 2003), show a correlation between attitude towards conservation, support for protected area and the acquisition of benefits from wildlife based tourism. The association can be seen by statements such as this one referring to the VNWR, "Its one of the aspects that makes Vieques unique for a tourist destination”. Not only did these individuals in the tourism sector have a higher positive attitude, but they also displayed knowledge about the importance of environmental protection in terms of ecotourism. The following quote from a survey respondent within the tourism sector demonstrates similar attitude and ecological awareness; “[VNWR] Protects an ecosystem that no longer exist in the Caribbean....and it's important to Vieques because it brings ecotourism”. The respondent also mentioned how the Caribbean is mostly overdeveloped and that the NWR keeps Vieques from reaching a similarly unfortunate future. 
Where individuals were born resulted to be an independent variable that influences attitude scores. Residents born in Vieques have an overall lower attitude score that those born elsewhere. Several factors come to play here that have been previously discussed. Primarily one can speculate that individuals born in Vieques have stronger ties to the history of the island and the presumed injustices of the federal government by the US Navy. Individuals born in mainland Puerto Rico, the incorporated US or other locations tend to have lived less time in Vieques and usually do not have family on the island. In addition, these individuals tend work in the tourism sector. That being said, it is understandable that these individuals will have a better disposition towards the FWS and the VNWR. Furthermore, when reviewing surveys from respondents born in USA, they do not display any negative attitude towards the federal government. Actually on the contrary, several expressed that they considered the Puerto Rican government to have a lack of capacity to manage itself.

Another variable influencing attitude was the participation of individuals in the protest against the Navy that occurred from 1999 until 2003. Participation in the protest relates again to the respondents ties to the history of Vieques and the apparent adversity caused by the federal government. Many Viequenses and fellow mainland citizens opposed military occupation and struggled for the cessation of military activities along with the reclaiming of their land for many years. The protest also revolved largely around safety, environmental protection, and health. The demands became the demilitarization, decontamination, devolution and sustainable development of the lands that were rightfully owned by the Viequense. During the protest there was a strong anti-colonial sentiment. Finally in 2003 the US Navy retreated from Vieques, however only 4,250 acres of the previously occupied land was transferred to the Municipality of Vieques and another 800 acres to the Puerto Rico Conservation Trust (Baver, 2012). The remaining 17,723 acres was transferred to the FWS, for the creation and management of the VNWR (Baver, 2012). This represents an incomplete fulfillment of the protester's demands. Even with the departure of the 
Navy there is still a legacy left behind of military relicts and contamination. In the past people of Vieques held opposition to the federal government due to the Naval occupation. Not surprisingly, for some residents the FWS has become the focus for local resentment because they view the Service as an extension of restrictions and absolute control over the land established by the navy (McCaffrey, 2008). Therefore, those who participated in the protest against the Navy have lower attitude scores compared to those not involved.

Another aspect the attitude score was subject to was fines or warnings, referring to whether the individual or one of their family members had received a fine or warning within the VNWR. As presented in the results, respondents who replied affirmatively had a lower mean attitude score when compared to those who had not. The lower attitude score is almost certainly the result of the resentment towards the imposing managing agency for the penalization and imposition of authority. As discussed previously, many respondents expressed discontent with the rules and regulations in the refuge. Thus, being penalized for violating a restriction that they do not agree with can be cause for a negative attitude towards the FWS and the VNWR. Additionally, when residents were asked through an open-ended follow up question about the experience of receiving the disciplinary action, some stated that the treatment by FWS law enforcement was unpleasant. In particular one law enforcement officer was mentioned by name quite often for abusing authority.

On the basis of these connections and influences, one can see why it was possible to not find a correlation between education and attitude score. Furthermore, although there is a correlation between awareness score and attitude, it is very weak. Knowing the regulations of the refuge, the land's ecological importance, and the safety hazards related to areas with restricted access become irrelevant to a certain extent to the way they perceive the refuge and their attitude towards it. The history of the island, the situations the people lived through during the naval presence and the current limitations that they perceive as an extension of the federal government 
dominance seems to have a substantial encumbrance on attitude. The association can be seen with almost half of respondents (48.1\%) wanting the lands remain as a PA and another $16.6 \%$ wanting to keep only part of the lands as a PA, meanwhile only 34.9\% wanting it to remain in the hands of the federal government with the FWS. Meaning that although many participants were in favor of the PA, not all of them want the FWS managing the land; instead several want the municipal or commonwealth government to be control of the PA. Consequently it seems that the negative associations with the VNWR might not only be a mere lack of knowledge about conservation or aversion to the protected area but rather contempt towards the federal government and the managing agency. Moreover, there might even be a feeling of distrust or cynicism towards the federal government for those who live through the naval presence as expressed by this participants comment: “It's ironic, so many years bombing the environment and now they protect it”. All of these factors together add to the convoluted reasoning behind resident's attitudes towards the wildlife refuge, and essentially why attitude scores are not quite inclined to be very positive or very negative in the population as a whole.

\subsection{Awareness of the Vieques National Wildlife Refuge}

When looking at the variables of age and time in Vieques, the same general trend is observed in the form of a weak negative correlation between the independent variables and the dependent awareness score. As mentioned before age and time in Vieques are associated to a certain extent. Again education and outreach influence the correlation between age and level of awareness. Younger respondents, being exposed to the informative programs offered by the FWS within a formal educational institution and through activities held in the refuge, have a higher awareness score. Part of the increased awareness among individuals living less time in Vieques can be attributed to age. However, there are other factors that might be involved and interconnect, thus they are discussed later. 
As expected, individuals working in the tourism sector, as well as those with a higher level of education were more familiar with the VNWR. What wasn't so expected was that birthplace had an influence on awareness, with respondents born in the incorporated US having a higher awareness score than those born in Vieques. When looking at why this occurs, there are several connections found. Individuals born in the US tend to have higher levels of education. Another aspect possibly influencing awareness scores is that a large amount of Vieques residents born in the US work in the tourism sector, thus they are expected to be more familiar with the VNWR. Finally, people from the US have lived less time on Vieques. Thus, this connects back to why individuals living less time in Vieques have a higher awareness score, because they are more educated and more of them tend to work in tourism.

Finally, individuals using the refuge for consumptive and non-consumptive uses had more knowledge of the refuge as expected. If you are visiting the NWR and conducting activities you will be more exposed to coming in contact with information and interacting with employees, which would lead to increase awareness. In addition, those who have received a fine or warning within their household have less awareness on the refuge based on questions asked. This again was expected and rational, that those who are not as familiar with the refuge and its ecological value might be more prone to violate the regulations in place.

\section{Conclusion \& Recommendations}

It was found that there is a combination of factors influencing attitude towards the VNWR. This includes socio-economic factors, misconceptions and the history of the island with its former military occupation. Older individuals and those who have lived more time in Vieques have poorer attitudes towards the VNWR then their counterparts. The trend is possibly associated with a more vivid history of the island and the earlier impacts of military presence. Those who were not born in Vieques tended to have lived less time on the island and subsequently had a 
generally positive attitude. Tourism also influences positively attitude scores. Awareness of ecological importance and refuge did not strongly correlated to attitude, due to other factors influencing. The most common complaints about the refuge in terms of natural resource use such as prohibitions on coconuts resulted from misconceptions. Other complaints included access and time restrictions.

Awareness towards the NWR's in terms of ecological importance, rules and regulations, and presence of military relics was correlated with some of the same factors. The longer individuals live in Vieques or the older they are leads to decreased awareness. Meanwhile, working in tourism and higher education both results in higher awareness. Individuals born in the USA had higher awareness scores, and this was also linked to living less time in Vieques, higher education, and more individuals within this sector of the population working in tourism.

On the basis of my results outreach and education should increase and expand to target all sectors of the population. Education should also not only inform about ecological importance but also its economic benefits such as sustainable ecotourism. Increased partnerships with community organizations might help target this broader population and additional scope of information. In addition education on my areas are closed off, and signage should also be created to resolve negative attitudes arising from misconceptions. This includes signs indicating coconuts and sea grapes may be taken for personal consumption. Furthermore, an increase in opportunities for nightly activities that do not conflict with conservation goals should be considered as this could positively impact attitudes.

Further research should be conducted to identify if any changes in attitude and awareness occur throughout time, using this study for comparison. Research can also expand on questions regarding resource use and demographic variables such as income. In addition, future studies could target an increase sample size. 
III. QUALITATIVE ANALYSIS OF KEY INFORMANT INTERVIEWS: Evaluating the Perceptions and Attitudes Towards the Vieques National Wildlife Refuge

\section{Introduction}

The concept of protecting natural or semi-natural areas has been around for millennia. However, in the rather recent past and with strict forms of conservation many rural people dependent on local natural resources were marginalized. The inaccessibility to natural resources often undermined conservation goals by resulting in growing tensions within park-people relations and ultimately drove a global change in protected areas management along with associated research (Heinen, 2010). In the realm of social science research focused on conservation, many studies (e.g. Torn et al. 2008; Szell \& Hallett, 2013) suggest that it is essential to address local people’s perceptions in the management of conservation areas. Negative perceptions can potentially create conflicts in protected areas management while more positive perceptions may be beneficial in attaining conservation goals. The understanding of social and economic factors regarding these perceptions may also be important to creating and following effective conservation plans in order to better mitigate negative or false beliefs.

In the United States one type of protected areas designation is a National Wildlife Refuge (NWR), which is managed by the US Fish and Wildlife Service (USFWS). There are over 560 units that form part of the NWR system. The refuge system follows a dominant use policy where the primary goal is related to conservation, management, and restoration of wildlife and related resources. Meanwhile, secondary uses such as recreation can exist meanwhile not compromising primary goals. In general, secondary uses commonly occur in wildlife refuges that relate to traditional, cultural, recreational and/or economic activities. Therefore, it is important to understand social dimensions of NWRs including these secondary uses despite not being the Refuges' main goal as it can affect management and conservation goals. 
Another important factor to consider is an incipient type of NWR, which has been referred to in various publications (e.g. Havlick, 2007, 2011, 2014; Hourdequin \& Havlick, 2011) as a military-to-wildlife (M2W) refuges. These NWRs arise from former military lands such as military bases, weapons depots, and sites of military training that have been decommissioned and reclassified. Theses sites are unique and important because of the paradox they present and its implications to management and conservation practices. Due to the complexity of former military activities, theses sites can contain both the high biodiversity and high contamination. This is due to a characteristic pattern presented by these sites: a heavily impacted core, surrounded by areas that were essentially sheltered from anthropogenic disturbances because they served as buffer zones and access was significantly restricted (Havlick, 2011).

The idea of including a social research agenda in protected areas management can be could be applied to M2W refuges. Most of these sites face unique health and safety hazards to both the public and the environment when compared to traditional NWRs. This in turn can lead to restricted access, management limitations and diverse public opinions. In addition, public perception towards these protected areas many be influenced by social, economic, and political issues related to the M2W conversion. According to Havlick (2007), there are currently twentyone M2W refuges in the US and its territories. One example that received noteworthy international news coverage during the end of its military occupation is the Vieques National Wildlife Refuge (VNWR). For some residents of Vieques, the FWS became the focus for local resentment because they view the Service as an extension of restrictions and absolute control over the land established by the navy (McCaffrey, 2008). Broadly, all protected areas must deal with park-people relations and perceptions of local residents. However, in certain ways M2W refuge officials must deal with unique and even novel types of perceptions due to the complexities of issues that relate to theses sites, as one can see with the case of the VNWR. 
Vieques is an island municipality that forms part of the Commonwealth of Puerto Rico, located just seven miles off the southeast coast of Puerto Rico’s mainland. The island's more recent history is filled with environmental, health and social conflicts revolving around the presence of the United States (US) Navy during the past 60 years. The US government expropriated nearly three-quarters of Vieques in the 1940's, displacing local residents from their homes for the establishment of a base and training facility (Baver, 2012). Residents of the island were exposed for years to the externalities arising from naval training conducted from 1941 to 2003 (McCaffrey, 2006). Viequenses and fellow mainland citizens opposed military occupation and struggled for the cessation of military activities along with the reclaiming of their land. In 2003 the US Navy retreated from Vieques, however only 4,250 acres of the previously occupied land was transferred to the Municipality of Vieques and another 800 acres to the Puerto Rico Conservation Trust (Baver, 2012). The remaining 17,723 acres was transferred to the Fish and Wildlife Service (FWS), for the creation and management of the Vieques National Wildlife Refuge (NWR) (Baver, 2012). Thus lead to an incomplete fulfillment of Viequenses' aspirations during their struggle, which included the recovery of the people’s previously owned land.

After the cessation of military activities over a decade ago, there is still a legacy of contamination inherited by US Navy occupation due to warfare training and related activities that released hazardous substances into the environment (McCaffrey, 2008). Furthermore, the unexploded ordnance left behind poses further health and safety issues (McCaffrey, 2006). Due to these hazards several areas on and around Vieques where designated as Superfund sites and listed as national priority (McCaffrey, 2006; Baver, 2006). As required by US federal law and under the mandate of the EPA, the designation of a Superfund site requires the responsible party (in this case US Navy), to cleanup the hazardous area. However, this decontamination process is slow and local government has no decision-making capacity or input. Likewise, the FWS lacks the capacity or the authoritative power to accelerate the cleanup process even while they do 
collaborate with the US Navy, which is in charge of decontamination activities. According to the FWS, due to the threat theses areas pose to safety and health, large parts of the NWR are closed to the public and the Service currently implements no management practices until decontamination is completed (Fish and Wildlife Service, 2007). Additionally, areas that are open to public access are accompanied by a series of restrictions, such as visitation hours limited to the daytime, or stricter rules on certain activities such as crab or shell gathering (Davis, HayesConroy \& Jones, 2007).

Although the local communities' attitudes and involvement seem to be an important factor in protected areas management, this is commonly not the case. Protected areas are still set aside without a priori knowledge or input from local communities and, in too many places, local communities are marginalized (Heinen, 2010). In a parallel situation, the Vieques NWR was designated under Congressional law without involvement or consultation of local communities, the municipal government, or the Government of the Commonwealth of Puerto Rico. There was also no consideration of the socio-economic conflicts that would emerge from this action.

Protected areas such as NWRs and their associated government agencies have been historically underfunded and understaffed, as is the case of Vieques NWR, which has only 12 staff members. Thus, community involvement is essential for the rules and regulations instituted by managers to be effectively followed and enforced (Tissot et al., 2009). However, in the past decades the people of Vieques opposed the federal government due to the Naval occupation. Furthermore, people have been know to trespass restricted areas as stated by various public notices issued by the Vieques NWR management during 2005, which shows a lack of compliance with regulations. Not surprisingly, for some residents the FWS has become the focus for local resentment because they view the Service as an extension of restrictions and absolute control over the land established by the navy (McCaffrey, 2008). During the interview of 10 households in the study by McCaffrey (2006), this resentment was presented by some individuals, along with an 
attitude of indifference by others. In news articles dating from 2003-2006, and more recently, 2013 (e.g. CBS, El Nuevo Día), there is a perception of resistance to the FWS. However, there have been no studies conducted on an overall assessment of Vieques residents with regard to their views towards the NWR and the FWS. Furthermore, a study of attitudes towards the VNWR from key groups such as fishermen, ecotourism operators, community leaders and refuge employees has not been completed. This research proposes to analyze the perception and attitudes of these key stakeholders through interviews and semi-structured conversations. The general idea is that these key informants will be more informed, have stronger opinions and be more directly impacted by the VNWR, thus providing a wider scope of knowledge.

The goal of this research is to determine the perceptions of key informants and groups of interest toward the Vieques National Wildlife Refuge (VNWR). Conflicts that may arise from these perceptions will also be elucidated to help make management recommendations. The specific objectives are to: 1 ) assess overall perceptions of residents of Vieques towards the NWR, 2) assess perceptions and attitudes towards the Vieques NWR in relation to socio-economic and demographic factors, 3) determine the local community's level of knowledge in regards to the

Vieques NWR, and 4) Identify enforcement and compliance issues that may arise from local perceptions.

\subsection{Site Description}

The study was conducted in the island municipality of Vieques that forms part of the Commonwealth of Puerto Rico, an unincorporated territory of the United States of America. The island is located just seven miles off the southeast coast of Puerto Rico's main island on the geographical coordinates $18^{\circ} 7^{\prime} 29.8956^{\prime \prime} \mathrm{N}, 6^{\circ} 26^{\prime} 31.6428^{\prime \prime} \mathrm{W}$. Vieques has a land area of about $127.4 \mathrm{~km} 2$, with a length of approximately $33 \mathrm{~km}$ and width of $7 \mathrm{~km}$ (Bauer et. al, 2008). Over half of the island is designated as a National Wildlife Refuge with the residents and tourist 
residing in the central part of the island. The entire VNWR accounts for 17,769 acres of land, with 14,623 acres in the eastern side and 3,100 acres in the western side. It is the largest Refuge in the Caribbean Islands NWR Complex. In the eastern portion of the VNWR, most of the access is restricted except a series of beaches while the clean up remains in process. In addition, 900 acres of land are designated as a Wilderness area, thus will remain largely inaccessible to the general public. According to the 2010 Census Bureau, the island had 9,301 residents and 3,666 households. The economy of the island has been increasingly relying on tourism both directly and indirectly, with thousands of visitors coming yearly. However, Vieques is still one of the poorest municipalities of PR. It has an unemployment rate of $10.1 \%$ and approximately $43.2 \%$ of the population living below the poverty level according to the American Community Survey 5-Year Estimates reported by the U.S. Census Bureau in 2013. Many Viequenses relay on secondary jobs or natural resource extraction in order to support their household income. In particular, fishermen and those in ecotourism depend heavily on the island's biodiversity. This subpopulation might be more subjected to the management and regulations of the VNWR. Overall Vieques is a rural island municipality.

The island and surrounding water has a warm and humid climate characteristic of a tropical marine environment (Bauer et. al, 2008). Temperature is relatively constant throughout the year, with highs and lows ranging between $29-32^{\circ} \mathrm{C}$ and $19-22^{\circ} \mathrm{C}$. Meanwhile, precipitation is characterized by seasonal (wet/dry season) and spatial fluctuations, with occasional tropical cyclones. The spatial distribution of rainfall across the island varies with a general gradient in which precipitation increases from the east to west due to differences in elevation that range from lower to higher. This in turn reflects upon the distribution of primary vegetation types. Furthermore, vegetation is also in different stages of succession due to the former land uses. Vieques falls within the subtropical dry forest and subtropical moist forest life zones (USFWS, 2008). There are various vegetation communities some of which are beach, coastal 
strand forest, mangrove, subtropical dry forest and shrub, mixed evergreen-deciduous forest and grassland. The variety of terrestrial and surrounding aquatic ecosystems in the VNWR support native, endemic, migratory, rare and protected of which sixteen are federally listed. The surrounding waters of Vieques are characterized by a variety of estuarine and marine habitats, most notably large expanse of seagrass beds, coral reefs and three rare bioluminescent bay ecosystems. The sandy beaches of the island provided nesting grounds for globally threatened Chelonia mydas (Green Turtle), Eretmochelys imbricate (Hawksbill), and Dermochelys coracea (Leatherback) sea turtles. The critically endangered Acropora cerviconis (staghorn coral) and Acropora palmate (elkhorn coral) are both found in the reefs surrounding Vieques along with over 200 identified fish species. Meanwhile, there are over 170 bird species including both migratory and residents such as the Melanerpes portoricensis (Puerto Rican woodpecker), Sterna dougallii (Roseate Tern), and the Falco peregrinus (Peregrine falcon). In coastal regions the blue land crab Cardisoma guanhumi can be found, which is a species of cultural and economic importance for the people of Vieques. In terms of plant species, according to the USFWS (2007), there are 27 rare and 5 federally listed plant species. This includes Eugenia woodburyana (Woodbury's stopper), Goetzea elegans (Mata buey), Calyptranthes thomasiana (Thomas’ lidflower), Chamaecrista glandulosa var. mirabilis (Puerto Rico Senna) and Stahlia monosperma (cóbana negra). Overall, the biodiversity in the VNWR provides an opportunity for conservation in addition to a base for sustainable socio-economic activities.

\section{Methods}

\subsection{Data Collection}

Many studies (e.g. Shrivastava \& Heinen, 2007; Moorman, 2006; Baptiste \& Nodenstam, 2009; Sesabo et al., 2006; Garcia-Lozano \& Heinen, 2015) have used social science research tools to examine the human dimensions of natural resource use, conservation, and protected areas 
management. Some useful tools for examining protected areas management, effectiveness and conflicts with local community as discussed by Heinen (2010), included survey and non-survey based techniques such as key informant interviews, rapid rural appraisal, and semi-structured social surveys. This can provide an insight on conflicts that arise from perceptions and attitudes of local communities or target groups. This can also provide an understanding of the past and current management practices in a protected area as well as socio-political factors that are involved as in the case of nature reserves in Kyrgyzstan (Ter-ghazaryan \& Heinen, 2006). In particular, key informant interviews have been a useful tool for researchers (e.g. Dongol \& Heinen, 2011; Shrestha-Acharya and Heinen 2009; Suman, Shivlani, \& Milon, 1999) to study policy implementation, regulations, and management of protected areas. Thus, in this study the data collection was conducted through key informant interviews. Some were informal guided conversations and others semi-structured open-ended interviews. A total of 33 individuals including FWS employees, refuge outfitters, government officials, community leaders, NGO members and local fishermen were part of this investigation. The snowballing technique, along with informal conversations with numerous local residents, was used to identify key informants. Some of the general questions asked included time living in Vieques, about their current positions or occupations, their participation during the anti-naval protest, and their opinions towards the VNWR. Questions about the VNWR included opinions with regard to rules, management, socioeconomic effects and overall perception. In addition questions were asked about ecological importance, land control and the contamination as well as the clean up process. The interviews were conducted in Spanish and transcribed and translated to English.

\subsection{Data Analysis}

This data were analyzed in a qualitative form by identifying themes and common ideas based on some of the fundamental components of grounded theory methodology as described by Charmaz, (2014) such as memo-writing, comparisons, categories and concepts. Key informants 
can be divided into four different groups: refuge ecotourism outfitters $(n=9)$, fishermen $(n=9)$, government agency personnel $(n=11)$, and NGO members $(n=4)$. Data was analyzed and compared within key informant groups (e.g. government) as well between them (e.g. fishermen vs. ecotourism outfitter). Based on the themes that arise, these were variables used to explain respondents’ attitudes, perceptions and level of awareness.

\section{Results \& Discussion}

There were varying attitudes within all four key informant groups. Fishermen displayed primarily negative attitudes towards the VNWR and FWS. The majority of government and ecotourism outfitter respondents on the contrary, had overall positive attitudes towards the VNWR and FWS. Meanwhile, the key informants belonging to the NGO group had the same number of individuals with positive attitudes as those with negative. Furthermore, the common ideas within a group that appeared to persuade their attitude also overlapped on instances between groups.

\subsection{Fishermen}

In the fishermen group, informants were all born in Vieques. One individual was retired and another was not a fisher per se but instead ran a small scale fish market. The rest of the participants within the group actively fished at least seasonally or part-time. These individuals targeted mixed species with mixed gear. One fisherman for example did SCUBA diving to harvest queen conch and spiny lobster. Another focused on catching blue land crabs seasonally. Meanwhile, two other fishermen use pots or traps and line fishing to catch mixed species. Within this key informant group, it is important to note that several individuals had additional sources of income. For example, one respondent in addition to fishing owned a business and another worked in construction. Three respondents were also activist that had been very involved during the 
Naval protest and still remained engaged in activism regarding federal government control over former naval lands, controversial practices implemented during the cleanup process, and the perceived environmental injustices endured by the Viequenses.

All participants classified as fishermen complained about regulations on fishing, from seasonal closures to size restrictions. These regulations are not limited to the VNWR, but rather are imposed island wide. The complaints come from how regulations affect fishermen's livelihoods. Most informants also mentioned their dissatisfaction with prohibition on blue land crabs. To their dismay, this prohibition exists in all PAs throughout the Puerto Rican archipelago managed by the DRNA. However, it's important to note that various informants were not aware of the limited permits granted by the FWS. This represents a lack of knowledge of opportunities available within the refuge. Nonetheless, those that were aware of the permits remained discontent with how blue land crabs are being managed. They stated that quotas were insufficient and that during the Naval presence this was a common practice that was allowed. They explained that catching land crabs was both recreational and a form of income for some. Although some individuals associated all of these regulations with FWS, others understood that many of the policies were created by other government agencies and were merely enforced by FWS. In particular, many of these rules come from the Departamento de Recursos Naturales y Ambientales (DRNA) under the 2010, Puerto Rico Fishing Regulations (Num. 7949, Chapter 1, Article 8.21). For those who associate the policies directly to FWS, this fuels their negative attitudes. Among the interviewees, on stated "The greatest damage we the fishermen did to the fishing in Vieques was to get the Navy out of here I swear on my mother”. Most informants did not comprehend the conservation objective behind fishing restrictions. One respondent even claimed that fishing in Vieques did not have any impact on fisheries, thus regulations were not necessary. Another participant who did admit to understanding the purpose of sizing restrictions stated that fishermen knew this and did not take undersized catch. Therefore, he asserted that 
regulating laws did not need to be implemented because fishermen can self regulate. However, it does not always appear to be the case. Through informal conversation with fishermen outside of these interviews, some admitted to collecting undersized fish. Several argued that economic constraints drove them to make that decision. Meanwhile others reasoned that releasing catch was a waste because the fish was going to die anyway.

All individuals in the fishermen key informant group also complained about area and time restrictions within the refuge, not only in relation to fishing but also for general recreation. Based on these interviews and additional informal conversation, it became evident that access and time regulations particularly impacted those who harvest near shore and might either disembark their vessels or practice on shore fishing. For example two individuals within the fishermen group stated that they collect bait near shore in waters adjacent to restricted areas within the refuge. They admit to having been intervened with by FWS employees because they would anchor their boats and from the intertidal zone uses nets to catch these fish. Furthermore, it became evident that although commercial fishermen do not fish onshore for the most part, there are a number of individuals that fish recreationally and for personal consumption in this zone. This is important to note within a rural island such as Vieques with limited economic resources. Here fishing can serve as a supplementary form of income or food source to alleviate high cost of commodities in an island dependent mainly on imports. Onshore fishing is also a cultural form of recreation for many. Finally, although most showed contempt towards restrictions on access to areas and time regulations two individuals admitted the need for regulations because they say that "pagan justos por pecadores” meaning the innocent pay for the sins of the guilty. These two individuals considered that regulations were in place because some individuals do take advantage and would conduct unlawful activities without law enforcement presence.

Other complaints included how law enforcement official mistreated residents and abuse their power. One informant even suggested that they should improve their communication and 
provide more orientation when intervening with people. Some additional complaints that came up were unfortunately fallacies such as several participants in the group complaining about not being able to take sea grapes or coconuts. One surprising complaint by two respondents was that there were surveillance cameras throughout the refuge and this upset them greatly. This displays again a lack of knowledge that impacts perception.

Overall, respondents in the fishermen group expressed animosity towards the VNWR and the FWS. Only three out of the nine participants within the group expressed a neutral perception, conveying both the pros and cons that they saw in regards to the VNWR and the FWS as the land manager. These three individuals, although admitting to not liking some of the regulations, understood the ecological importance of wildlife conservation and how it pertains to their interest in the fishing sector. They did however still want FWS to be a bit more flexible in their regulations. The other participants expressed a strong dislike for the federal government and complete dissatisfaction with regulations. They did not necessarily all understand the ecological importance especially in terms of marine resources and its interconnection with nearby terrestrial ecosystems. All respondents agreed that there were more liberties when the Navy was present, though not to say that they agreed with the military practices that took place. Some admittedly see the FWS as an extension of the Navy with absolute authority. One respondent used the common idiom in Vieques, "FWS is the same dog with a different collar" (direct translation from English to Spanish), referring to the FWS being the same as the Navy. Another said, "We did not get the Navy out, we just stopped the bombing”. Finally, six out of the nine individuals in this group wanted the FWS to leave Vieques and the VNWR lands to be given to Vieques. There were discrepancies in proposed land use, but overall the theme was development of the region with proposals such as hotels, housing, marinas, and even agricultural areas. Some did mention the need for conservation of certain areas, but it wasn't clearly articulated how it would be achieved. 


\subsection{Refuge Ecotourism Outfitter}

Key informants that belong to the refuge ecotourism outfitters group displayed a generally positive attitude towards the VNWR and the FWS as land managers. Within this group respondents all had permits with the FWS, and conducted regular tourism activities within the refuge. They all agreed that the FWS permitting process was much simpler than the process for acquiring permits with DRNA or any other Puerto Rican government agency. Within this group, two respondents were born in Vieques, while the others seven were either from the main island of Puerto Rico or continental US. Among the non-Vieques born participants, some have been living in Vieques for up to 25 years, others have been visiting the island since early childhood, and a couple also have family in Vieques. The larger companies with multiple employees also state that they employ a number of Vieques born individuals. This is mentioned because through informal conversations and in some interviews, the idea that the tourism is dominated by foreigners or nonViequenses came up several times. The key informants in this group showed that there are a variety of entrepreneurial individuals from different geographic origins within the tourism sector. These individuals have businesses ranging from zero to twenty employees.

When conducting the key informant interviews for this group, one of the themes that came up was the ecological importance bestowed upon the VNWR by respondents. They all agree that some of the most important advantages of the VNWR was the conservation of wildlife and ecosystems, in addition to the protection of natural resources for now and future generations. Not only did they value the ecology of the refuge for its intrinsic value, but they also expressed an economic value of the islands ecology generated by tourism. "Many of the tourists come to the island because people want to see pristine things”, states a business owner and eco-touristic guide. They view this as a really advantage provided by having a NWR in Vieques. Actually most consider that since the departure of the Navy and the creation of the refuge that tourism has increased. Along with the increase in tourism, they think that this has the potential to improve the 
economy if it has not done so already. However, some of the outfitters considered that several external factors including lack of adequate infrastructure hamper the economic growth.

Moreover, all respondents mentioned something very important to consider. In their opinions, most of Vieques' residents lack knowledge of the ecological importance of the refuge lands. One outfitter state, "Unless they can see it as money that they can put in their pocket, they don't care”, referring to the general publics opinion on the NWR and ecology of the island. Nevertheless, when outfitters were asked if they considered if the FWS was doing an effective job in education and community outreach, all except one participant agreed. This is ironic, based on the previous statements. When further looking at the data, it becomes apparent that although youth awareness and outreach is mentioned on multiple occasions, no other demographic sector is mentioned. Outfitters even affirm that youth outreach is what is most important. They consider that FWS is doing the best they can with the federal bureaucratic system and economic resources allocated to them. The respondent that did not agree that FWS was conducting successful outreach remarks: "I think that the people of Vieques are not given sufficient information on the real treasure it is to have that NWR”. He recognized that although FWS does some education and outreach, they could do more. This outfitter states that more information should be available to the general public about what is being protected in the refuge and the reasoning behind regulations or actions taken in order to improve perceptions.

Based on interviews with this group, their perception is that there is a division among the general population with those that agree with the creation of the NWR and the presence of the FWS, and those that disagree. However, most of the participants thought that opinions had changed and were changing to more positive attitudes. One key informant says, "People were very adamant about the VNWR but now they are more welcoming to the idea of the refuge”. Some of the animosity regarding the refuge is attributed to land control and regulations, according to the outfitters. 
In terms of the group’s opinion, they personally agree with all or at least some of the rules and regulations within the refuge. Some mention that there could be more flexibility within the norms. Points of dispute include access to more areas especially beaches and extended hours. Although most generally agreed that there are no disadvantages to having a NWR in Vieques, several participants did reiterate these issues as possible shortcoming of the refuge. Moreover, most respondents did acknowledge comprehension of safety factors regarding restricted areas and economic limitation hindering the availability of personnel required for extended hours of aperture. Another comment that came up as a deficiency of the refuge was the lack of food vendors.

One important thing to point out that arose from these interviews is the desire for some outfitters to conduct nocturnal tours. Furthermore, based on one of the participant's accounts, this is already an option during special nights that the refuge is open for fishing. Permitted outfitters could take advantage of this, but unfortunately it seemed that many did not know about it. This ties back to the level of knowledge and outreach that is given to the general population as well as specific groups. Other comments that were mentioned and represent a possible lack of knowledge include complaints by two individuals about coconut, sea snails and hermit crab restrictions.

All except one participant within the ecotourism group stated that the VNWR lands should remain under the control of the federal government with the FWS. Thus was due to their expressed lack of trust in both the municipal government and commonwealth government. The common premise was that either level of government would be quick to sell the lands off to the highest bidder or otherwise leave them abandoned. Is due to past incidents with lands that were given back to the municipality after the cessation of military activities. The one respondent who did not agree, wanted the lands to be ceded to the municipality of Vieques and used for tourism related development. He did mention though that certain areas such as the beaches do need to be 
conserved for tourism. Furthermore, he clearly stated it should be for the development of the local economy and not for large corporations.

\subsection{NGOs}

This was the smallest group, with 4 individuals interviewed. Two belonged to the Vieques Conservation and Historical Trust (VCHT), one was from Radio Vieques, and the other from La Incubadora. These three NGOs have different institutional goals in Vieques that the interviewees conveyed along with on occasions their personal opinions. The general attitude towards the refuge was divided; with participants form VCHT having positive attitudes towards the refuge while those from Radio Vieques and Incubadora Micro-Empresas Biekes being more negative. There were also different themes that arose such as land devolution, development, ecological conservation, and education.

The VCHT was established in 1985 and is a non-profit organization dedicated to the conservation of Vieques' natural and cultural resources through informal educational activities, research facilitating partnerships and community outreach. During the time of Naval occupation in Vieques, the NGO never became involved in the protests because of its institutional regulations that prohibit political stances. However, the VCHT did denounce the environmental impact resulting from military exercises. They also clearly stated that the VCHT did not have anything against the Navy per se. On the other hand, members within the NGO do have their own convictions and differ in their opinions towards the navy and subsequently FWS presence.

In light of their mission of resource conservation and involvement in education activities, it was not surprising to find that the VCHT collaborates frequently with the FWS and VNWR. On many occasions the NGO takes groups of children, elders, or members of community organizations to the refuge on educational fieldtrips. When FWS has big events VCHT collaborate and vice versa. Finally they have also used the VNWR for research and collaborate 
with common research partners. Based on these experiences, the individuals interviewed express the VCHT having a positive relation with the refuge and its employees. They see that the work that is being done in the refuge is positive. They also affirm that the VNWR serves as a platform for ecotourism and economic development, which is encouraging for the people of Vieques.

When discussing their posture on the FWS managing the former naval lands as a NWR, the interviewees could not give an opinion because of the nature of the NGO's regulations. However, they did provide their interpretation on the general community's views towards the land designation and managers. They find that some individuals have a positive outlook, while others do not. They consider that some of the individuals unenthusiastic about the refuge are ignorant about its ecological importance and conservation needs. More importantly, the respondents also articulated an inherent distrust rooted from the islands history. According to one VCHT member, it will take constant outreach through generations to deal with this aspect of local resident's perceptions. Furthermore, she made an important point that because of that same history a lot of individuals have not been able to see many of the refuge lands that are closed off. This can influence the distrust and ignorance as well, because most of the locals have not even seen many areas that are being restored and conserved. She also admits that many of the pictures that have been shared are limited to images presenting military impact mostly during the time of anti-naval protest. This adds to expressions made by the other respondent, "Many consider that a total degradation or lost of habitat has occurred in former military or industrial use lands, which is not always the case”.

Opinions and perceptions differed greatly when speaking to the participants from the other two NGOs, Radio Vieques and Incubadora Microempresa Bieke. According to interviewees, both of these organizations arises from the Comite Pro Rescate y Dessarrollo de Vieques (Committee for the Rescue and Development of Vieques). This was a community-based organization that started in the 1990's with the purpose of resuming the resistance that began in 
the 1970s and 1980s to end the military presence in Vieques and achieve subsequent sustainable development. The station focuses on cultural and educational programing including local and regional topics in additional to a focus on solidarity and socially conscientious music. Meanwhile, Incubadora Microempresas Bieke is a community-based NGO founded to help reduce poverty levels in Vieques by facilitating the creation of micro-business and self-employment through mean of consulting, training, and workshops provided to the local residents. Based on the history these two NGOs share it was not uncommon to have encountered similar perceptions towards the VNWR.

Some of the main themes that were found during these interviews included demands for land devolution, dissatisfaction with FWS presence, and the aspirations of a sustainable socioeconomic development within the hands of the local community. These themes have strong ties with the history of the island and social injustices. First and foremost, the fact that the former naval lands were not ceded to Vieques represents an incomplete fulfillment of the demands that existed during the anti-naval protest. Hence, this can provoke resentment towards the presence of a protected area managed by a federal agency that is part of the same government that allowed the presence of a Naval base for years. Furthermore, the dissatisfaction with the FWS is fueled by mistrust and a perceived lack of transparency in the agency. Statements made by the informant from Radio Vieques portray this, "FWS should have been there with the people of Vieques protesting against the destruction of fishing and wildlife”. He talks about how it was an insult to have FWS as land managers after the people of Vieques fought for decades to recuperate the land in the absence of the agency and without their environmental concerns.

The control of almost half of the island by an external government agency is seen as an impediment to socio-economic development. Furthermore, both respondents considered that the majority of the economy of Vieques was in hands of foreigners. The Incubadora Micro-empresas Bieke even states that FWS is biased providing more accessible permits to non-native residents. 
There is also an interest to develop certain areas within the NWR in a sustainable way, although there is a mention for conservation of ecologically fragile lands as well. Notably, they did not mention the conservation of inland regions that are associated with costal areas although; they do talk about the ecological importance of beaches, lagoons, and tributaries.

\subsection{Government}

FWS employees and other government personnel were interviewed in order to acquire greater insight on park-people relations within the VNWR. All key informants within this group expressed positive attitudes towards the work FWS is doing towards conservation and land management. They also identified several of the common fallacies that had been expressed by not only the general public, but also some of the other informant groups. In addition, light is shed on challenges that these civil service employees encounter.

Among the fallacies about the VNWR, the most commonly stated misconception was that collecting coconuts for personal consumption would result in monetary penalties. All refuge employees attested that the only instance that coconuts would be regulated is in the case of commercial uses. Likewise, this would only require the acquisition of a permit to collect the coconuts and does not imply an imminent ban. Furthermore, they affirmed that the same applied to other natural resources such as sea grapes. Other misconstructions that were corroborated included the prohibition of sea snails and hermit crabs. Sea snails are used for consumption; meanwhile hermit crabs serve as bait for fishing. When speaking to FWS officials, they clarified that there are no federal or commonwealth laws prohibiting the collection of these species. However, they did explain that there are sizing regulations are defined by the DRNA and these are enforced by the FWS. Additionally, the refuge director and law enforcement officer expressed their intent on identifying appropriate quotas on these species to ensure sustainable resource use.

Among the fallacies that admittedly challenge FWS employees, there are other related points commonly contested. Employees varied in opinion on the topic of outreach and education. 
Although some vouched that the FWS was doing positive outreach in all sectors of the community, others expressed this being one of the biggest challenges in management. One employee expresses that although they are conducting successful outreach with children, the general population is more difficult to influence. A statement from the VNWR manager further communicates this: "I think that the largest management issue in regards to people, in reality is education on the importance of the conservation and natural resources of Vieques”. According to him, most of the community does not understand or is not interested in the importance of Vieques' ecology to the Puerto Rican archipelago and the Caribbean. Furthermore, for many if there is no economic value attached to something, then there is no concern for its conservation. Thus education must go beyond imparting intrinsic values of the island's ecology and aim towards empowering the community to feel ownership over the natural resources. In addition, to an understanding of how through conservation this can ultimately benefit the local economy. Consequently, broadened educational efforts are necessary and outreach is a challenge in management efforts.

Throughout the dialogues during this research, the topic of land devolution came up many times. During the anti-naval protest among the demands was the devolution of lands. During household surveys and key informant interviews several individuals expressed a desire for the VNWR lands to be ceded to the municipal government of Vieques. Some individuals expressed that they wanted the lands to be used in other ways that did not involved protected areas for conservation. However, others did want the lands to remain as a protected area but instead put under the management of the municipal government. Two commonly conveyed reasons for the desire of land devolution were a sentiment of rightful ownership and the idea that the municipal government would have better management practices to benefit the local community. Nonetheless, the town mayor voiced his contentment with the FWS managing the former refuge lands as a NWR. He explained that ecological conservation was very important, 
FWS was managing the lands well and they even provided support to the community outside of their jurisdiction. Moreover, he admitted that if the lands were to be given to the municipal government they lacked the manpower and economic resources to manage it. He even alluded to the difficulties in land control and management that the municipal government encountered with the western parcels that were bestowed upon them.

Finally, one optimistic piece of information found through these interviews is that all respondents believe that the perceptions and attitudes of the residents of Vieques have improved since the creation of the NWR. This is of course merely an opinion, but it is noteworthy to mention as other informant groups have stated the same thing. Participants believe that the integration of Viequense employees in the FWS, effective outreach and education, and community involvement has helped ameliorate the initially adamant attitudes. In addition, it could be plausible to think that tensions were very high when the Navy left and there was doubt of this new federal agency coming in. With time, FWS has been able to demonstrate the transparency of their wildlife conservation goals.

\section{Conclusions and Recommendations}

A theme that came up constantly within the majority of individuals that displayed negative attitudes towards the VNWR was how it impeded the development of the lands, hence the socio-economic development of the island. The concept of development they articulated was mostly in terms of hotels, lodges and beachfront properties. Although they did express that some conservation should be done, this seems to be contradictory with their concept of development. Overall, they did not seem to fully comprehend the ecological importance of the lands within the VNWR. In particular, the connection between terrestrial and aquatic ecosystems was not understood. 
Based on several other key informants, there is a lack of knowledge of the ecological importance and conservation activities within the general population. It also became evident that there is an opportunity that is facilitated by the VNWR and FWS to do ecotourism activities within the refuge as a means of generating revenue for outfitters that are both native and nonnative residents. Furthermore, it seems that with time, resident's perceptions and attitudes towards the VNWR have improved based on the overall opinions of key informants. However, it is evident that there is still a long way to go, with individuals still being very adamant against the presence of the refuge and managing agency.

In terms of research, further studies that could be conducted including key informant interviews with ecotourism outfitters that do not operate within the VNWR. It could be of interest to see if their opinions about the refuge vary and why they choose not to operate within refuge grounds. Also, future studies could be conducted to compare perception and attitude data from this study and identify any changes that may occur with time.

As for recommendations to the VNWR, there should be an increase in outreach that broadens to all sectors of the population of Vieques. This should include topics of what the FWS does, what is conserved within the VNWR, and why it is important. Possibly monthly newsletters should be produced maybe with the collaboration of NGOs to get information out through multiple means. Education should also broaden to include how conservation can be the foundation of a sustainable ecotourism based economy. Simple signage should be added to beaches regarding coconuts and sea grape extraction to avoid misconceptions. Finally, there should be continued efforts of community integration and empowerment over the natural resources available and its conservation. 


\section{FINAL IMPLICATIONS AND OVERALL CONCLUSIONS}

It is important to understand that the purpose of this thesis was not necessarily to affirm the validity of certain statements expressed by those interviewed or surveyed during this research, but rather to express their points of views and how these influence their attitudes towards the VNWR and FWS. Although it was of interest to identify misconceptions about regulations and these are presented, this work does not intend to assert the veracity of other statements such as those related to the expropriations or military impacts on human health. By shedding light on resident's attitudes, perceptions, knowledge, and misconceptions it is possible to make recommendations concerning management, education, and outreach efforts. Land managers, NGOs, and local government can take advantage of this information in order to improve not only park-people relations, but also to increase the socio-economic benefits that can come from conservation. Furthermore, this work presents a means by which the general opinions of the people of Vieques are voiced. That is of inherent importance, considering that this is a group of people that have been deemed by many as historically marginalized.

Based on the results of this study we can conclude that there are very few individuals with strong positive or negative attitudes towards the VNWR. It was also possible to deduce that the economic benefits from the tourism sector and an increase level of knowledge correlate with improved attitudes toward the wildlife refuge. Furthermore, effective outreach and education efforts targeting youth as described by several of the key informants could be correlated with better attitudes within younger age groups. However, there is still a need for increased outreach since there are sectors of society that lack knowledge of the ecological importance according to both survey data and interviews. Furthermore, several misconceptions fuel adverse attitudes. This includes fallacies of absolute bans on coconuts, sea grapes, sea snails and hermit crabs. This is something that refuge employees also expressed they were aware of, however it continue to be a 
common misconception. Another topic that arose frequently included refuge access, both in terms of areas and time day. This of course derives from former land use and current clean up process, which impact management and accessibility notably. Unfortunately, many considered these limitations to have been established by FWS or they do not understand the reason for these regulations (e.g. the possibility of live munitions in some areas), thus adversely impacting attitudes.

Finally, there are deep-rooted social and historical factors that effect resident's attitudes. Those that engaged in anti-naval protest and those still engaged in activism tended to have the most negative attitudes towards the refuge. It is important to considered the past and how it affects the present. Years of military presence and perceived injustices, lead to distrust and dissatisfaction with current land managers. Although some individuals will never change their opinion, it might be possible to improve attitudes through continued outreach. Furthermore, it might be necessary to embrace that past, honor it, incorporate it into the story of the VNWR, and encouraging residents to feel ownership of the islands natural resources even within the refuge. Outreach could be broadened to include ideas of FWS as caretakers of the natural resources that belong to the people of Vieques, and how residents can benefit through conservation and sustainable socio-economic uses. 


\section{IIV. REFERENCES}

Allendorf, T. D., K. K. Swe, T. Oo, Y. Htut, M. Aung, K. Allendorf, L. A. Hayek, P. Leimgrubek \& C. Wemmer. (2006). Community attitudes towards three protected areas in upper Burma. Environmental Conservation, 33(4), 344-352.

Allendorf, T. D. (2007). Residents' attitudes toward three protected areas in southwestern Nepal. Biodiversity Conservation, 16(7), 2087-2102.

Aminrad, Z., Zakaria, S. Z. S., Hadi, S., \& Sakari, M. (2013). Relationship between awareness, knowledge and attitudes towards environmental education among secondary school students in Malaysia. World Applied Sciences Journal, 22(9), 1326-1333.

Arcury, T. (1990). Environmental attitude and environmental knowledge. Human organization, 49(4), 300-304.

Bauer, L.J., Menza, C., Foley, K.A., and Kendall, M.S. (2008). An ecological characterization of the marine resources of Vieques, Puerto Rico. Part I: Historical data synthesis. Prepared by National Centers for Coastal Ocean Science (NCCOS) Biogeography Branch in cooperation with the Office of Response and Restoration. Silver, Spring, MD. NOAA Technical Memorandum NOS NCCOS 86. 121 pp.

Baral, N. \& J. T. Heinen. (2007). Resource use, conservation attitudes, managerial intervention and park people relations in the Western Terai Landscape of Nepal. Environmental Conservation, 34(1), 64-72.

Baver, S. (2006). Peace is More than the End of Bombing: The Second Stage of the Vieques Struggle. Latin American Perspectives. 33(1), 102-115.

Baver, S. (2012). Environmental struggles in paradise: Puerto Rican cases, Caribbean lessons. Caribbean Studies, 40(1)

Bradley, J. C., Waliczek, T. M., \& Zajicek, J. M. (1999). Relationship between environmental knowledge and environmental attitude of high school students. The Journal of Environmental Education, 30(3), 17-21.

Briggs, D. (2009). Plant microevolution and conservation in human-influenced ecosystems. Cambridge University Press. p. 356

Cruz Pérez, R. (1998). Contaminación producida por explosivos y residuos de explosivos en Vieques, Puerto Rico. Dimension 8, no. 2:37-42.

Davis, J. S., J. S. Hayes-Conroy, and V. M. Jones. (2007). Military Pollution and Natural Purity: Seeing Nature and Knowing Contamination in Vieques, Puerto Rico, GeoJournal, 69, 165179.

Dudley, N. (Editor) (2008). Guidelines for Applying Protected Area Management Categories. Gland, Switzerland:IUCN. x + 86pp. 
Fiallo, E. A. \& S. K. Jacobson. (1995). Local communities and protected areas: Attitudes of rural residents towards conservation and Machalilla National Park, Ecuador. Environmental Conservation, 22(3), 241-249.

Fischman, R. (2002). The National Wildlife Refuge System and the hallmarks of modern organic legislation. Ecology law quarterly, 29, 457.

Fischman, R. L. (2003). The national wildlife refuges: Coordinating a conservation system through law. Washington, D.C.: Island Press.

Garcia Lozano, Alejandro J., "An Institutional, Socio-economic, and Legal Analysis of Fisheries Co-management and Regulation in the Gulf of Nicoya, Costa Rica" (2014). FIU Electronic Theses and Dissertations. Paper 1539. http://digitalcommons.fiu.edu/etd/1539

Garcia Lozano, A. J., \& Heinen, J. T. (2015). Identifying Drivers of Collective Action for the Comanagement of Coastal Marine Fisheries in the Gulf of Nicoya, Costa Rica. Environmental management, 1-11.

Gemmill, Daphne. (2015). Birds of Vieques Island, Puerto Rico: status, abundance, and conservation. Special issue of The Journal of Caribbean Ornithology, BirdsCaribbean; Charlottesville, VA: Scholarly \& Specialized Publishing.

Havlick, D. (2007). Logics of change for military-to-wildlife conversions in the United States. GeoJournal, 69(3), 151-164.

Havlick, D. (2011). Disarming nature: Converting military lands to wildlife refuges. Geographical Review, 101(2), 183-200.

Havlick, D. (2014). Opportunistic conservation at former military sites in the United States. Progress in Physical Geography, 1-15.

Heinen, J. T. (1993). Park-people relations in Kosi Tappu Wildlife Reserve, Nepal: A socioeconomic analysis. Environmental Conservation, 20(1): 25-34.

Heinen, J.T. (2010). The importance of a social science research agenda in the management of protected natural areas, with selected examples. Botanical Review 76, 140-176.

Heinen, J.T. \& R. J. Shrivastava. (2009). A demographic and socio-economic analysis of conservation attitudes and awareness around Kaziranga National Park, Assam, India: Implications for conservation and development. Pop. Environ. 30(6), 261-274.

Hourdequin, M., \& Havlick, D. G. (2011). Ecological Restoration in Context: Ethics and the Naturalization of Former Military Lands. Ethics, Policy \& Environment, 14(1), 69-89. doi:10.1080/13668791003778891 
Langhorne, E. (1987). Vieques: History of a Small Island. The Vieques Conservation and Historical Trust. Vieques, PR.

Marques, L. \& Fernandez-Portes, J. (2001). El impato ambiental de las actividades de la Marina de Guerra de Estados Unidos en Vieques. Exégesis. Revista de la Universidad de Puerto Rico en Humacao. 14 (38/40): 38-44

McCaffrey, K.T. 2002. Military Power and Popular Protest: The U.S. Navy in Vieques, Puerto Rico. Rutgers University Press.

McCaffrey, K. T. (2006a). The Battle for Vieques' Future. Centro Journal 18 (1):124-147.

McCaffrey, K. T. (2006b). Social Struggle against the U.S. Navy in Vieques, Puerto Rico: Two Movements in History. Latin American Perspectives, 33(1), 83-101.

McCaffrey, K.T. (2008). The Struggle for Environmental Justice in Vieques, Puerto Rico. David Carruthers, ed., Environmental Justice in Latin America: Problems, Promise and Practice. MIT Press.

McCaffrey, Katherine. (2009). Fish, Wildlife, and Bombs: The Struggle to Clean Up Vieques. NACLA Report on the Americas 42 (Sept.-Oct.): 35-41.

Mumby, P. J., Edwards, A. J., Arias-González, J. E., Lindeman, K. C., Blackwell, P. G., Gall, A., ... \& Wabnitz, C. C. (2004). Mangroves enhance the biomass of coral reef fish communities in the Caribbean. Nature, 427(6974), 533-536.

Nazario, C.N., Suarez, E. L., and Perez, C. (1998). Analysis critico del informe incidencia de cancer en Vieques del Departamento de Salud de Puerto Rico. Recinto de Ciencias Medicas, Universidad de Puerto Rico.

Haskell, B. D., Leeworthy, V. R., Wiley, P. C., Beuttler, T. M., Haflich, M. R., Delaney, J., ... \& Franklin, E. (2000). Tortugas Ecological Reserve. Final Supplemental Environmental Impact Statement/Final Supplemental Management Plan. NOAA, Silver Spring, MD.

Hoffsomer, John C. and Glover, Donald J. Explosives Chemistry Branch, Naval Surface Weapons Center. Vieques Litigation Support: Explosives Analyses of Water and Soil Samples taken on Vieques Island, Puerto Rico, May 11 through May 16, 1978

O’Connell, S., Ku, T, and Martini, A., (2007). The hydrodynamics and biogeochemistry of bioluminescent bays, Vieques, Puerto Rico. 20th Annual Keck Symposium. The College of Wooster.

Roque, A. (2011). A Social Survey of Demography and Attitudes of Residents Regarding the Protected Area in Puerto Morelos, Mexico. FIU Electronic Theses and Dissertations. Paper 480.

Runte, A. (1997). National parks: the American experience. U of Nebraska Press.

Tissot, B. N., Walsh, W. J. and Hixon, M. A. (2009). Hawaiian islands marine ecosystem case 
study: ecosystem and community-based management in Hawaii. Coastal Management, 37(3), $255-273$.

Torn, A., P. A. Siikamaki, A. Tolvanen, P. Kauppila \& J. Ramet. (2008). Local people, nature conservation and tourism in Northeastern Finland. Ecol. Soc., 13, 8.

Turner, A. G. (2003). Sampling strategies. Handbook on designing of household sample surveys. Geneva: United Nations Statistics Division.

Sekhar, N. U. (2003). Local people's attitudes towards conservation and wildlife tourism around Sariska Tiger Reserve, India. Journal of environmental Management, 69(4), 339-347.

Sesabo, J. K., Lang, H., Tol, R. S. J. (2006). Perceived attitude and marine protected areas (mpas) establishment: why household's characteristics matter in coastal resources conservation initiatives in Tanzania. Working Papers. FNU-99 1-39.

Sharma, C., \& Rajagopalan, R. (2013). Marine protected areas: securing tenure rights of fishing communities. Land Tenure Journal, (1).

Shrivastava, R. J. \& J. T. Heinen. (2007). A microsite analysis of communities around Kaziranga National Park, India: Implications for conservation and development. J. Environ. Dev., 16, 207-216.

Suman, D., Shivlani, M., \& Milon, J. W. (1999). Perceptions and attitudes regarding marine reserves: a comparison of stakeholder groups in the Florida Keys National Marine

Sanctuary. Ocean \& Coastal Management, 42(12), 1019-1040

Shivlani, M. (2007). Community studies to determine the feasibility and expectations of marine protected area (MPA) management in Vieques, Puerto Rico. Miami, Fla: University of Miami, Rosenstiel School of Marine and Atmospheric Science

Stolton, S., P. Shadie and N. Dudley (2013). IUCN WCPA Best Practice Guidance on Recognising Protected Areas and Assigning Management Categories and Governance Types, Best Practice Protected Area Guidelines Series No. 21, Gland, Switzerland: IUCN.

Szell, A.B., \& Hallett, L. F. (2013). Attitudes and Perceptions of Local Residents and Tourists toward the Protected Area of Retezat National Park, Romania. International Journal of Humanities and Social Science, 3(4), 18-34.

Vedeld, P., Jumane, A., Wapalila, G., \& Songorwa, A. (2012). Protected areas, poverty and conflicts: A livelihood case study of Mikumi National Park, Tanzania. Forest Policy and Economics, 21, 20-31.

Weil, E. (2004). Puerto Rico. Department of Marine Sciences, University of Puerto Rico.

Woodbury, R.O. (1972). Section VII: Vegetation In Vieques 1972 Survey of the Natural Resources. Environmental Quality Board, Commonwealth of Puerto Rico: Office of the Governor 
U.S. Census Bureau. (2009). State median family income by family size. Retrieved from http://www.census.gov/hhes/www/income/statemedfaminc.html

U.S. Census Bureau. (2013). 2009-2013 5-Year American Community Survey. Retrived from http://factfinder.census.gov/faces/nav/jsf/pages/community_facts.xhtml

U.S. Fish and Wildlife Service. (2007). Vieques National Wildlife Refuge Comprehensive Conservation Plan and Environmental Impact Statement. U.S. Department of the Interior Fish and Wildlife Service, Atlanta, GA. August, 2007 


\section{IIIV. APPENDIX}

ENTREVISTA PARA RESIDENTES DE VIEQUES, P.R.

1. Edad__ 2. Género: M F $\quad$ 3. Nivel mas alto de educación

4. Número de adultos en la casa , de niños (menor de 18) Total:

5. Ocupación de adulto(s):a) b) c) d)

6. Cuánto tiempo ha vivido en Vieques (años)

7. ¿Tus padres son de Vieques? (¿que generación?)

8. ¿ंTiene usted alguna otra familia en Vieques?

9. ¿Algún individuo de su familia fue expropiado por la Marina?

10. Ciudad natal/estado/país

11. ¿Trabaja usted dentro del sector de turismo? Sí No

Responde, NO: ¿Su trabajo depende indirectamente del sector de turismo? Sí No

12. Las finanzas actuales de su familia dependen de la presencia del refugio nacional de vida silvestre? Sí No

13. Ha visitado alguna vez el Refugio nacional de vida silvestre de Vieques? Sí No ¿Si NO, Por qué no?

14. ¿Qué actividades realiza usted en el refugio actualmente? (mencione todas)

15. ¿Qué actividades te gustaría llevar a cabo en el refugio que no se permiten? (mencione todas)

16. ¿¿Está usted al corriente de las reglas de manejo y regulaciones del refugio?

Sí No Algunas

¿En caso afirmativo, cómo usted se familiarizo con ellas? 
17. ¿Está usted a favor de las reglas? Sí, todas Sí, algunos No

Por favor explique su respuesta anterior: (respuesta abierta)

18. ¿Conoce algún empleado del refugio? Sí No

19. ¿Estaba de acuerdo con la creación del refugio? Sí No ¿Porqué si o porqué no? (respuesta abierta).

20. Por favor circule la respuesta que mejor se adapte a su opinión sobre cada declaración:

a. El personal del refugio es profesional y cortes: de acuerdo neutral desacuerdo no sabe

¿Porqué? (respuesta abierta)

b. En general, el refugio se maneja bien: de acuerdo neutral desacuerdo no sabe

¿Porqué? (respuesta abierta)

21. ¿Cuáles son las principales desventajas de tener el Refugio Nacional de Vida Silvestre en Vieques? (enumere todas)

22. ¿Cuáles son las principales ventajas de tener el Refugio Nacional de Vida Silvestre en Vieques? (enumere todas)

23. ¿Se ha enterado usted o ha recibido información/invitación de reuniones publicas referente al refugio? Sí No

24. ¿Usted ha asistido alguna vez a una reunión pública referente al refugio? Sí No En caso afirmativo, la experiencia fue: Positiva Neutral Negativa Explique por favor su respuesta anterior (respuesta abierta): 
25. ¿Si hubiese recibido información le gustaría o le interesaría ir a una reunión pública referente al refugio? Sí No ¿Si NO, Por qué no?

26. Por favor circule la respuesta que mejor se adapte a su opinión sobre cada declaración o pregunta:

a. ¿Usted y su familia estaban mejor económicamente cuando estaba la marina en Vieques? Sí No

¿Por qué?

b. ¿ ¿Usted y su familia están mejor económicamente desde que se creo el Refugio nacional de vida silvestre?

Sí No

¿Por qué?

b. ¿ Usted y su familia preferirían que los terrenos del Refugio permanezcan bajo el control del gobierno federal de los EE.UU. (FWS) o quisiera que se cediera a otra agencia gubernamental o institución?

Gobierno federal de EE.UU. Otra agencia o institución Ninguno de los anteriores (¿Cual?):

¿Por qué?

d. ¿En caso de ceder los terrenos a otra agencia o institución, deben los terrenos permanecer una área protegida (para la conservación del medio ambiente) o ser utilizados de otra manera?

Permanecer como área protegida Utilizados de otra manera

En caso de utilizar de otra manera, explique como: 
e. Mi familia y yo incurrimos en menos riesgos de salud y seguridad desde que se fue la Marina y se creo el Refugio Nacional de Vida Silvestre? Sí No ¿Por qué?

f. ¿¿En general, pudieras decir que estas contento que los antiguos terrenos de la marina en Vieques ahora son un Refugio nacional de vida silvestre? Sí No

g. ¿Desde que se creo el refugio nacional de vida silvestre, has recibido información acerca de su importancia ecológica? Sí No

¿Cómo llegó usted a ser informado?

h. ¿Desde que se creo el refugio de vida silvestre nacional, has recibido información acerca de los posibles problemas de salud y seguridad asociados con los restos militares de la zona (UXO/ bombas sin detonar/contaminación etc.)? Sí No

¿Cómo llegó usted a ser informado?

27. ¿Considera usted que los terrenos del refugio nacional de vida silvestre tiene importancia ecológica?

Sí No

28. ¿Qué considera que es ecológicamente importante en el Refugio Nacional de Vida Silvestre? (mencione todo)

29. ¿Usted o algún miembro de su familia ha sido alguna vez advertido o ha recibido una multa por infringir las reglas establecidas en el refugio y sus áreas protegidas? Sí No

En caso afirmativo, por favor explique (respuesta abierta)

30. ¿Participo usted en “La lucha contra la Marina”?

Sí $\quad$ No

31. ¿Qué te gustaría para el futuro del Refugio Nacional de Vida Silvestre?

32. ¿Hay alguna otra cosa que quisiera comentar o añadir? 